University of Nebraska - Lincoln

DigitalCommons@University of Nebraska - Lincoln

Agronomy \& Horticulture -- Faculty Publications

Agronomy and Horticulture Department

3-18-2019

\title{
Development of a nitrogen recommendation tool for corn considering static and dynamic variables
}

\author{
Laila A. Puntel \\ University of Nebraska-Lincoln, Ipuntel2@unl.edu \\ Agustin Pagani \\ Clarion Inc., Buenos Aires \\ Sotirios V. Archontoulis \\ lowa State University, sarchont@iastate.edu
}

Follow this and additional works at: https://digitalcommons.unl.edu/agronomyfacpub

Part of the Agricultural Science Commons, Agriculture Commons, Agronomy and Crop Sciences Commons, Botany Commons, Horticulture Commons, Other Plant Sciences Commons, and the Plant Biology Commons

Puntel, Laila A.; Pagani, Agustin; and Archontoulis, Sotirios V., "Development of a nitrogen recommendation tool for corn considering static and dynamic variables" (2019). Agronomy \& Horticulture -- Faculty Publications. 1249.

https://digitalcommons.unl.edu/agronomyfacpub/1249

This Article is brought to you for free and open access by the Agronomy and Horticulture Department at DigitalCommons@University of Nebraska - Lincoln. It has been accepted for inclusion in Agronomy \& Horticulture -Faculty Publications by an authorized administrator of DigitalCommons@University of Nebraska - Lincoln. 


\title{
Development of a nitrogen recommendation tool for corn considering static and dynamic variables
}

\author{
Laila A. Puntel, ${ }^{1}$ Agustin Pagani, ${ }^{2}$ and \\ Sotirios V. Archontoulis ${ }^{1}$
}

\author{
1 lowa State University, 3401 Agronomy Hall, Ames, IA 50014, USA \\ 2 Clarion Inc. Nueve de Julio, Buenos Aires, Argentina \\ Current address for L.A. Puntel - Department of Agronomy and Horticulture, \\ 102D Keim Hall, University of Nebraska-Lincoln, Lincoln, NE 68583-0915, USA; \\ email Ipuntel2@unl.edu
}

\begin{abstract}
Many soil and weather variables can affect the economical optimum nitrogen $(\mathrm{N})$ rate (EONR) for maize. We classified 54 potential factors as dynamic (change rapidly over time, e.g. soil water) and static (change slowly over time, e.g. soil organic matter) and explored their relative importance on EONR and yield prediction by analyzing a dataset with $51 \mathrm{~N}$ trials from Central-West region of Argentina. Across trials, the average EONR was $113 \pm 83 \mathrm{~kg} \mathrm{~N} \mathrm{ha}^{-1}$ and the average optimum yield was $12.3 \pm 2.2 \mathrm{Mg} \mathrm{ha}^{-1}$, which is roughly $50 \%$ higher than the current $\mathrm{N}$ rates used and yields obtained by maize producers in that region. Dynamic factors alone explained $50 \%$ of the variability in the EONR whereas static factors explained only $20 \%$. Best EONR predictions resulted by combining one static variable (soil depth) together with four dynamic variables (number of days with precipitation $>20 \mathrm{~mm}$, residue amount, soil nitrate at planting, and heat stress around silking). The resulting EONR model had a mean absolute error of $39 \mathrm{~kg} \mathrm{~N} \mathrm{ha}^{-1}$ and an adjusted $\mathrm{R}^{2}$ of 0.61 . Interestingly, the yield of the previous crop was not an important factor explaining EONR variability. Regression models for yield at optimum and at zero $\mathrm{N}$ fertilization
\end{abstract}

Published in European Journal of Agronomy 105 (2019), pp 189-199

doi 10.1016/j.eja.2019.01.003

Copyright $\odot 2019$ Elsevier B.V. Used by permission.

Submitted 16 June 2018; revised 10 January 2019; accepted 11 January 2019; published 18 March 2019. 
rate as well as regression models to be used as forecasting tools at maize planting time were developed and discussed. The proposed regression models are driven by few easy to measure variables filling the gap between simple (minimum to no inputs) and complex EONR prediction tools such as simulation models. In view of increasing data availability, our proposed models can be further improved and deployed across environments.

Keywords: Optimum nitrogen rate recommendation, Corn, Decision support tools, Precision agriculture, Argentina, Site-specific management

\section{Introduction}

Maize production in Argentina has doubled over the last five years from 20 to 40 million tones (AMIS, 2018). About $80 \%$ of the grain produced is exported annually, making this region important in the global maize market (Alexandratos and Bruinsma, 2012; Andrade and Satorre, 2015). The increased corn production has been mainly associated with an increase in farmable area rather than productivity. The Central-West region's average corn yield is $7.6 \mathrm{Mg} \mathrm{ha}^{-1}$, which is considerably below the potential yield of $16 \mathrm{Mg} \mathrm{ha}^{-1}$ (Andrade and Satorre, 2015). Poor crop management, in particular nitrogen $(\mathrm{N})$ fertilization, is the major reason for the yield gap. The average $\mathrm{N}$ application rate to corn in this region is about $61 \mathrm{~kg} \mathrm{~N} \mathrm{ha}^{-1}$ (Bolsa de Cereales, 2018), which is about half of the US Corn Belt average $\mathrm{N}$ rate (Sawyer et al., 2006). Increasing $N$ fertilization results in increased production costs that depending in the year, soil type, and landscape position this investment may or may not pay off due to the multiple factors affecting the economic optimum $\mathrm{N}$ rate (EONR, Puntel et al., 2018).

A better understanding and predictability of the EONR variability in this region could result in higher yields and profits while reducing environmental impacts (Aparicio et al., 2008). However, there is little research on EONR in Central-West Buenos Aires compared to other regions such as the US Corn Belt (Scharf and Lory, 2006; Dhital and Raun, 2016). Interestingly, the vast majority of published studies on EONR have focused on the effects of individual factors such as soil properties or precipitation as opposed to the compound effect of multiple factors on EONR (Mamo et al., 2003; Basso et al., 2001, 2013; Albarenque et al., 2016). To our knowledge, in Argentina the most common $\mathrm{N}$ recommendation methods is the soil $\mathrm{N}$ test at $60 \mathrm{~cm}$ depth before planting (Ruiz et al., 2001) or at 6th leaf stage at $30 \mathrm{~cm}$ (Sainz Rozas et al., 2000). However, other $\mathrm{N}$ recommendation methods have been evaluated in Argentina such as the $\mathrm{N}$ balance approach, stalk and plant $\mathrm{N}$ test (Sainz Rozas et al., 2001), crop sensors and remote sensing technologies (Ferrari et al., 2010), and a crop simulation model (Satorre and Mercau, 
2001). The majority of these tools does not account for spatio-temporal dynamics such as soil available water content at sowing (Gregoret et al., 2011; Coyos et al., 2018).

In general, factors affecting EONR and yield can be broadly classified into dynamic variables (ones that change quickly within a growing season such as precipitation) and static variables (ones that change slowly and do not vary within a growing season such as soil organic matter, SOM). Today's N recommendation tools are based on: 1) dynamic factors such as soil nitrate-N (Rozas et al., 2000; Shapiro et al., 2008), 2) static factors such as soil texture (Tremblay et al., 2011), 3) both static and dynamic factors via crop and soil modeling (Banger et al., 2017), 4) yield expectations (Stanford et al., 1973) and 5) multiyear- site average yield response to N curves (e.g. MRTN, Sawyer et al., 2006) without considering other factors.

Regarding the static variables, some studies have reported relationships between yield or EONR with soil texture and/or SOM (Gregoret et al., 2006; Peralta et al., 2013; Puntel et al., 2017). Soil texture and SOM affect water holding capacity and $\mathrm{N}$ cycling, thus soil $\mathrm{N}$ supply and crop N uptake (Sogbedji et al., 2001). However, measuring these static variables at a fine spatial resolution is expensive and labor intensive. To address this issue more accessible variables such as topography and apparent soil electrical conductivity (ECa) are used (Kitchen et al., 2003; Shaner et al., 2008). The ECa is correlated with soil water content (Brevik et al., 2006), soil compaction (Kravchenko and Bullock, 2000), and salinity (Heiniger et al., 2003) and it is a very good indicator of soil texture (King et al., 2005). Topography, derived terrain parameters, and ECa have been used with varying degrees of success to determine areas with contrasting yields (Chang et al., 2004) and differential yield response to N (Jaynes, 2011).

Regarding the dynamic variables, several studies have indicated the importance of soil moisture, soil nitrate, rainfall and temperature on crop yields and EONR in rainfed regions (Andrade et al., 1993). For example, Hergert et al. (1995) and Kitchen et al. (2005) illustrated the importance of spatial and temporal dynamics of soil nitrate on EONR. Ordóñez et al. (2015) and Edreira and Otegui (2013) quantified heat stress effects on corn yield and $\mathrm{N}$ uptake. Soil temperature and moisture affect soil $\mathrm{N}$ mineralization and residue decomposition and thus crop $\mathrm{N}$ availability and EONR (Andraski et al., 2000; Cabrera et al., 2005). Shallow groundwater dynamics have been found to positively affect yield in dry seasons and negatively affect yield in wet seasons (Jaynes, 2012; Nosetto et al., 2009) while also affecting environmental $\mathrm{N}$ losses (Dinnes et al., 2002) and thus the EONR.

Understanding which dynamic and static factors or synergic relationships contribute the most to spatial (between landscape positions) and temporal (between years) variability in EONR is complex and still elusive (Scharf, 
2015). Thus far, no study has been conducted to compare the relative importance of different static and dynamics factors on EONR and corn yield. A targeted experimental approach is needed in which several variables are simultaneously measured to identify the most important ones for further emphasis. To shed light on this important knowledge gap, we analyzed a dataset with $51 \mathrm{~N}$ response trials from Central-West Buenos Aires, Argentina in which numerous static and dynamics variables were measured. Our specific objectives were to: 1) identify the range of yield and EONR variability in this region, 2) quantify the relative importance of dynamic and static factors on yield and EONR, and 3) to synthesize gained knowledge and develop a predictive $\mathrm{N}$ model to aid site-specific $\mathrm{N}$ management.

\section{Material and methods}

\subsection{Experimental sites and design}

Fifty-three $\mathrm{N}$ rate trials were conducted at contrasting landscape positions and soil types, on five fields located in Nueve de Julio, Buenos Aires, Argentina during five growing seasons: 2012-2013 (season 1; 10 trials), 2013-2014 (season 2; 10 trials), 2014-2015 (season 3; 13 trials), 2015-2016 (season 4; 11 trials), and 2016-2017 (season 5; 9 trials). Soils were coarse-loamy, thermic Typic Hapludolls representing the most productive areas of the fields, coarse-loamy, thermic Entic Hapludolls mostly representing sandy hills with low productivity, and Thapto-argic Hapludolls corresponding to shallow soils due to the presence of a clay pan layer at varying depths. These soils are representative of the Central-West Buenos Aires Province and other provinces in Argentina. In addition, the area is influenced by a fairly shallow water table that responds rapidly to rain (Mejia et al., 2000). Due to severe flooding two trials were not harvested reducing the number of $\mathrm{N}$ trials used in the analysis to 51 .

The $\mathrm{N}$-trials were established in representative landscape positions with the goal to generate variability in elevation, ECa, soil nitrogen, soil properties, and previous crop productivity (e.g. summer soybean-corn or double crop spring wheat/summer soybean-corn rotations). As an example, Figure S1 illustrates the position of six $\mathrm{N}$ trials. Each $\mathrm{N}$-trial was a small-plot randomized complete block design with three replications. Seven $\mathrm{N}$ rates $\left(0,25,50,100,150,200\right.$, and $\left.250 \mathrm{~kg} \mathrm{ha}^{-1}\right)$ were applied as broadcasted urea between planting and third corn leaf stage (V3 stage; Abendroth et al., 2011). Plot size was $9 \mathrm{~m}$ long and $2.8 \mathrm{~m}$ wide. According to soil analysis, only phosphorus and sulfur were below optimum values, thus, fertiliz-

ers were applied according to soil analysis and local recommendations to 
ensure nutrient sufficiency. All trials had a final plant population between 65,000 and 80,000 plants ha-1 and row spacing was either $0.75 \mathrm{~m}$ or 0.52 $\mathrm{m}$. Commercial corn hybrids with a relative maturity of 120-125 days were planted around September 25th \pm 7 days. Fields were managed without tillage. Pest, diseases, and weeds were adequately controlled to ensure optimal growing conditions.

\subsection{Measurements and data processing}

Grain yields were determined by collecting ears from the center two rows of each plot ( $5 \mathrm{~m}$ length). Grain moisture was measured, and final yields were adjusted to $14 \%$ moisture content. Additional measurements were taken from each $\mathrm{N}$ trial to explain yield response to $\mathrm{N}$ including: SOM, texture, gravimetric water content, ECa, elevation, soil and water table depth, amount of residue from the previous crop, and hourly weather data. These measurements and subsequent calculations were classified into static and dynamic explanatory variables, which are described below and summarized in Table 1.

\subsubsection{Static variables}

Static variables are relatively constant over time and measured once per trial (Table 1). Soil apparent electrical conductivity at 30 and $90 \mathrm{~cm}$ depth was measured on transects, approximately 20m apart using a Veris model 3100 sensor cart system (Veris Technologies, Salina, Kansas, USA). The ECa surveys were conducted before planting or after harvest. Elevation data was obtained by a dual frequency RTK system (Trimble 5700, USA) connected to the EC Veris surveyor. Both ECa and elevation data points were interpolated using ArcGIS (ESRI, 2018, Redlands, CA, USA) and R software (R Core Team, 2018) using ordinary kriging in a regular 3-m grid (Figure S1).

Landscape characteristics were determined by primary and secondary terrain attributes (Moore and Grayson, 1991; Wilson and Gallant, 2000). We used primary attributes such as elevation, relative elevation (Rel_elev), slope, and plan curvature (pcurv) that were derived directly from digital elevation models (DEM) (Figure S1, Table 1). Secondary attributes such as specific catchment area (SCA) were derived from a combination of primary attributes. Digital terrain analysis was performed using the GRASS 7.0.5 (Geographic Resources Analysis Support System, grass.osgeo.org) and ArcGIS 10.5 software packages.

The r.param.scale function in GRASS was used to calculate plan curvature. The digital elevation model was processed using a neighborhood of 3 by 3 cells (equivalent to an analysis scale of $13.9 \mathrm{~m}$ ). The slope gradient and a moving-window version of relative elevation (REL; Miller, 2014) were calculated using custom toolbox models in ArcGIS 10.5, using custom toolbox 
Table 1. Description of static and dynamic explanatory variables.

\begin{tabular}{|c|c|c|c|}
\hline Acronym & Explanation & Unit & Observed range \\
\hline \multicolumn{4}{|c|}{ Static variables (change slowly over time or do not change) } \\
\hline OM_20 & Soil organic matter $(0-20 \mathrm{~cm}$ depth) & $\%$ & $2-4$ \\
\hline P_Bray_20 & Available Bray phosphorus (0-20 cm depth) & ppm & $6-51$ \\
\hline EC_20 & Electrical conductivity $(0-20 \mathrm{~cm}$ depth) & $\mathrm{ds} / \mathrm{cm}$ & $47-124$ \\
\hline pH_20 & $\mathrm{pH}(0-20 \mathrm{~cm}$ depth) & - & $5-6$ \\
\hline Sand_20 & Sand content $(0-20 \mathrm{~cm}$ depth) & $\%$ & $36-84$ \\
\hline Silt_20 & Silt content (0-20 cm depth) & $\%$ & $12-53$ \\
\hline Clay_20 & Clay content $(0-20 \mathrm{~cm}$ depth) & $\%$ & $3-16$ \\
\hline ECa_30 & Soil apparent electrical conductivity $(0-30 \mathrm{~cm}$ depth) & $\mathrm{ds} / \mathrm{m}$ & $3-19$ \\
\hline ECa_90 & Soil apparent electrical conductivity $(0-90 \mathrm{~cm}$ depth) & $\mathrm{ds} / \mathrm{m}$ & $4-28$ \\
\hline Elev & Elevation as meters above the sea level & $\mathrm{m}$ & $71-89$ \\
\hline Rel_elv & $\begin{array}{l}\text { Relative elevation using the middle elevation as the reference } \\
\text { (REL, Miller et al., 2014) }\end{array}$ & $\%$ & $-0.22-0.29$ \\
\hline planc & Plan curvature & deg & $-0.28-40$ \\
\hline Slope & Slope of the field & \%_raise & $0-5$ \\
\hline SCA & Specific catchment area & pixel value & $0-486$ \\
\hline $\mathrm{MO}(20-60)$ & Soil organic matter content (20-60 cm depth) & $\%$ & $1-3$ \\
\hline Sand $(20-60)$ & Sand content $(20-60 \mathrm{~cm}$ depth) & $\%$ & $36-84$ \\
\hline Silt $(20-60)$ & Silt content (20-60 cm depth) & $\%$ & $12-48$ \\
\hline Clay $(20-60)$ & Clay content (20-60 cm depth) & $\%$ & $5-20$ \\
\hline Soil_depth & Soil depth & $\mathrm{m}$ & $0.6-2$ \\
\hline \multicolumn{4}{|c|}{ Dynamic variables (change fast over time) } \\
\hline Residue_amount & Amount of residue from previous crop at planting & $\mathrm{kg} / \mathrm{ha}$ & 3636-10909 \\
\hline Residue_CN & Quality of residue as Carbon to $\mathrm{N}$ ratio & - & 30-75 \\
\hline Previous Yield & Yield of the previous crop & $\mathrm{kg} / \mathrm{ha}$ & $2000-6000$ \\
\hline N_20 & Nitrate content $(0-20 \mathrm{~cm}$ depth) & $\mathrm{kg} / \mathrm{ha}$ & 19329 \\
\hline$N(0-60)$ & Nitrate content $(0-60 \mathrm{~cm}$ depth) & $\mathrm{kg} / \mathrm{ha}$ & $28-116$ \\
\hline Water table & Water table depth & $\mathrm{cm}$ & $30-450$ \\
\hline SW_20 & Soil water content $(0-20 \mathrm{~cm}$ depth) & $\mathrm{mm}$ & $21-72$ \\
\hline SW $(20-60)$ & Soil water content (20-60 cm depth) & $\mathrm{mm}$ & $30-177$ \\
\hline FC_20 & Soil water as a $\%$ of field capacity at $20 \mathrm{~cm}$ & $\%$ & $43-237$ \\
\hline FC $(20-60)$ & Soil water as a \% of field capacity at 20 to $60 \mathrm{~cm}$ & $\%$ & $71-265$ \\
\hline FC_w & Soil water as a $\%$ of field capacity 0 to $60 \mathrm{~cm}$ & $\%$ & $65-253$ \\
\hline Max_20 & Soil water as a $\%$ of saturation point at $20 \mathrm{~cm}$ & $\%$ & $23-82$ \\
\hline $\operatorname{Max}(20-60)$ & Soil water as a \% of saturation point at 20 to $60 \mathrm{~cm}$ & $\%$ & $35-102$ \\
\hline Max_w & Soil water as a $\%$ of saturation point at 0 to $60 \mathrm{~cm}$ & $\%$ & $34-93$ \\
\hline SW_sum & Soil water content $(0-60 \mathrm{~cm}$ depth $)$ & $\mathrm{mm}$ & $57-277$ \\
\hline Events_P-S & Number of rain events from planting to silking & days & $9-28$ \\
\hline Amount_P-S & Cumulative rain from planting to silking & $\mathrm{mm}$ & $202-528$ \\
\hline Events_P-S_20 & Number of days with rain $>20 \mathrm{~mm}$ from planting to silking & days & $2-13$ \\
\hline Amount_P-S_20 & Cumulative rain (only $>20 \mathrm{~mm}$ ) from planting to silking & $\mathrm{mm}$ & $98-428$ \\
\hline Events_S & Number of rain events around silking ( \pm 1.5 weeks) & days & $1-8$ \\
\hline Amount_S & Cumulative rain around silking ( \pm 1.5 weeks) & $\mathrm{mm}$ & $25-176$ \\
\hline Events_S_20 & Number of days with rain $>20 \mathrm{~mm}$ around silking & days & $0-7$ \\
\hline Amount_S_20 & Cumulative rain (only $>20 \mathrm{~mm}$ ) around silking & $\mathrm{mm}$ & $0-150$ \\
\hline Events_H-P_E & Number of rain events from harvest to planting & days & $6-25$ \\
\hline Events_H-P_20 & Number of rain events (> $20 \mathrm{~mm}$ ) from harvest to planting & days & $2-12$ \\
\hline Amount_H-P_E & Cumulative rain from harvest to planting & $\mathrm{mm}$ & $140-866$ \\
\hline Amount_H-P_20 & Cumulative rain events (> $20 \mathrm{~mm}$ ) from harvest to planting & $\mathrm{mm}$ & $98-810$ \\
\hline Events_P-H_20 & Number of rain events from planting to harvest & days & $11-60$ \\
\hline Events_P-H_20 & Number of rain events (> $20 \mathrm{~mm}$ ) from planting to harvest & days & $2-18$ \\
\hline Amount_P-H_20 & Cumulative rain from planting to harvest & $\mathrm{mm}$ & $296-840$ \\
\hline Amount_P-H_20 & Cumulative rain (only $>20 \mathrm{~mm}$ ) from planting to harvest & $\mathrm{mm}$ & $78-672$ \\
\hline Temp_P-H_35 & Number of heat days (daily temp $>35^{\circ} \mathrm{C}$ ) around silking & days & 2-13 \\
\hline Temp_S_35 & Number of heat days from planting to harvest & days & $1-5$ \\
\hline Radiation_S & Classification of radiation around silking $* * *$ & - & $1-2$ \\
\hline Temp_P-H_10 & Number of cold days $\left(<10^{\circ} \mathrm{C}\right)$ from planting to harvest & days & $23-42$ \\
\hline
\end{tabular}


models (available at http://www.geographer-miller.com/relief-analysis-toolbox ). Plan curvature is perpendicular to the direction of the maximum slope. A positive value indicates that the surface is sidewardly convex at that cell. A negative value indicates the surface is sidewardly concave at that cell. A value of zero indicates the surface is linear (Figure S1). Profile curvature relates to the convergence and divergence of water flow across a surface. The SCA was calculated using Spatial Analyst Hydrology Tools in ArcGIS 10.5. The SCA is defined as the area of land upslope of a width of contour, divided by the contour width. This is a commonly used quantity in hydrology to describe complex terrain for analyzing water flow on hill slopes; it can be a surrogate for water discharge per unit flow width.

Soil organic matter was determined by the combustion method (Wang and Anderson, 1998) and texture by the pipette method (Soil Survey Staff, 2014). Ten cores were taken per block from 0 to 20, 20-60, 60-100 cm depth in most of the experimental sites to determine SOM and texture. For the first two seasons, samples were collected from 0 to 20, 20-40, and 40-60 $\mathrm{cm}$ depth (Sites 1-10). Data was combined into top $(0-20 \mathrm{~cm})$ and subsoil data $(20-60 \mathrm{~cm})$. Data below $60 \mathrm{~cm}$ was not used in the analysis. Effective soil depth, which stands for the depth of the pretocalcic horizon and/or claypan layer, was measured manually with a 1.2-meter soil probe in each plot. Soil depth was as shallow as $60 \mathrm{~cm}$ for some of the experimental sites. Using SOM, texture data, and Saxton and Rawls (2006) pedotransfer functions, we calculated field capacity (FC) and saturation point (SAT) for the top and subsoil layers.

\subsubsection{Dynamic variables}

Variables that change rapidly over time were classified as dynamic (Table 1). Gravimetric soil water and nitrate- $N$ contents at $0-20 \mathrm{~cm}$ and $20-60 \mathrm{~cm}$ were measured at planting. Soil water content was expressed as a percent of FC and SAT. Nitrate-N content was determined using the phenoldisulphonic acid method (Davis, 1916) and expressed as $\mathrm{kg}$ of $\mathrm{N}$ per ha by layer. The total nitrate- $\mathrm{N}$ amount across the $0-60 \mathrm{~cm}$ profile was used as an explanatory variable in this analysis. Water table depth at each trial was manually measured (from installed wells) around planting. Hourly precipitation, radiation, and temperature data was obtained from nearest weather station $(<5 \mathrm{~km})$ to the experimental sites. Precipitation was accumulated for the following periods: from harvest of the previous crop to planting of corn (amount_H$\mathrm{P})$, from planting to silking (amount_P-S), \pm 1.5 weeks around silking (critical period; amount_S), and from planting to harvest (amount_P-H). For the same time periods, we calculated and used as explanatory variables the number of rain events greater than $0 \mathrm{~mm}$ and greater than $20 \mathrm{~mm}$ per day (events_H-P, events_S, events_P-H, events_H-P_20, events_S_20, events_PH_20). The value of $20 \mathrm{~mm}$ day $^{-1}$ was arbitrarily chosen in this analysis to 
account for possible $\mathrm{N}$ leaching. The number of days with air temperature below $10{ }^{\circ} \mathrm{C}$ during the growing season, the number of days with air temperatures above $35^{\circ} \mathrm{C}$ around maize's critical period ( \pm 1.5 weeks around silking), and over the entire growing season were counted (Temp_P-H_10, Temp_P-H_35, Temp_S_35, respectively). Lastly, we calculated the radiation sums around the critical period (Radiation_S) as a proxy of crop growth rate that is known to affect kernel number.

Grain yield of the previous crop was estimated from yield monitor data at each experimental site. When yield maps were not available, yields of the previous crop at each site were estimated based on image analysis and yield records from the farmer. The amount of residue and its carbon (C)to-nitrogen ratio (C:N) was directly measured in season 4 (2015-16) in each block from an area of $1 \mathrm{~m}^{2}$. A subsample of the residue was analyzed for $C$, $\mathrm{N}$, and C:N ratio using the dry combustion method (LECO, 2008). Residue amount and quality for the other seasons were estimated from previously published grain yield and residue $\mathrm{C}: \mathrm{N}$ relationships for Argentina (Melchiori et al., 2014).

\subsection{Data analysis}

The relationship between yield and $\mathrm{N}$ rate was described from the quadratic and quadratic-plus-plateau models using R software (R Core Team, 2018). Models were deemed significant at $p<0.05$ and the equations with the smallest sums of squares and largest $R^{2}$ were selected (Table S1). The EONR and yield at the EONR (YEONR) was calculated from the $N$ response equations by setting the first derivative of the fitted response curve equal to a historical price ratio of 10:1 $\mathrm{N}$ : corn grain price (US\$ $\mathrm{kg}^{-1} \mathrm{~N}$ : US\$ $\mathrm{kg}^{-1}$ grain) ratio (Cerrato and Blackmer, 1990; Bullock and Bullock, 1994; Pagani et al., 2008). This price ratio is about half of what is used in the USA (5.6:1; Puntel et al., 2016). A sensitivity analysis of the effect of price ratios (5.6 and 14 vs $10 \mathrm{~N}$ : corn grain price) on EONR for three experiments is shown in Figure S6. Although optimum $\mathrm{N}$ rates would be slightly different if different prices were used, the optimal $\mathrm{N}$ rate is relatively insensitive to shifts in prices (Baethgen et al., 1989; Pagani et al., 2008). Maximum yield response to $\mathrm{N}$ was calculated as the difference between YEONR and Yield_NO.

Relationships between explanatory variables (Table 1) were explored using Pearson correlation, principal component analysis, and clustering (Figure S2). We excluded highly auto-correlated variables from subsequent regression analysis. Plant population and row spacing was considered random in the statistical analysis. The remaining static and dynamic variables were used to develop regression models for EONR, YEONR, and Yield_N0. The efficient branch-and-bound algorithm method within the leaps $\mathrm{R}$ package was used to produce a list of sub-models for consideration, and then we fit 
a linear model for each sub-model individually to obtain the selection criteria. The best model was selected based on adjusted $\mathrm{R}^{2}$ and $k$-fold (leaveone-out) cross validation error. Finally, we calculated performance indexes such as mean absolute difference (MAE) and root mean squares (RMSE, see equations in Archontoulis and Miguez, 2015).

We developed two types of regression models (Table 2). The first one, hereafter referred to as the full model, made use of all available information from harvesting of the previous crop to harvesting of the next crop. The second, hereafter referred to as the reduced model, made use of information from harvesting of the previous crop to planting time of the next crop.

To determine the relative importance of static and dynamic variables within the regression models we used the simple unweighted averages (Img) method (Gromping, 2006). This metric decomposes $\mathrm{R}^{2}$ into absolute contributions of different factors that sum to the total $R^{2}$. The advantage of this method over simpler metrics is that the Img is based on sequential $\mathrm{R}^{2}$, while accounting for the dependence on orderings using simple unweighted averages. This analysis was performed for the full and reduced model separately.

\subsubsection{Preliminary model testing}

We used an independent set with three N trials from the 2017-18 (Season 6) growing season to test the predictive capacity of both full and reduced models. This season had a severely dry summer $(244 \mathrm{~mm}$ of rain from planting to harvest; with only $30 \mathrm{~mm}$ around silking). The soils had a SOM from 2.2 to $3.5 \%$ and a sand content from 52 to $70 \%$. The previous season's crop was a double crop of spring wheat/summer soybean. All model inputs were calculated as described in previous sections.

Table 2. Mean absolute error for economic optimum nitrogen rate (EONR; units: $\mathrm{kg} \mathrm{N} \mathrm{ha}^{-1}$ ), yield at EONR (YEONR; $\mathrm{Mg} \mathrm{ha}^{-1}$ ), and yield at nitrogen zero (Yield_N0; $\mathrm{Mg} \mathrm{ha}^{-1}$ ) for regression model predictions using information from previous harvest until planting (reduced model) and using information available from previous crop harvest to next harvest (full model).

\begin{tabular}{|c|c|c|c|c|c|c|}
\hline \multirow{3}{*}{ Season } & \multicolumn{6}{|c|}{$\mathrm{kg} \mathrm{ha}^{-1}$} \\
\hline & \multicolumn{3}{|c|}{ In-season prediction (reduced model) } & \multicolumn{3}{|c|}{ At planting prediction (full model) } \\
\hline & EONR & YEONR & Yield_NO & EONR & YEONR & Yield_NO \\
\hline 1 & 49 & 1.3 & 0.7 & 52 & 1.2 & 1.2 \\
\hline 2 & 45 & 1.6 & 1.3 & 56 & 1.7 & 1.3 \\
\hline 3 & 40 & 1.4 & 1.1 & 37 & 1.7 & 1.6 \\
\hline 4 & 32 & 1.1 & 0.9 & 42 & 1.4 & 1.3 \\
\hline 5 & 24 & 2 & 1.3 & 35 & 1.8 & 1.4 \\
\hline All seasons & 43 & 1.2 & 1.3 & 39 & 1.1 & 1.0 \\
\hline
\end{tabular}




\section{Results}

\subsection{Spatial and temporal variability of the explanatory variables}

Season 1 was the wettest (23\% above regional average precipitation) and Season 2 was the driest (7\% below average precipitation; Figure S3). During the critical period of silking, the number of precipitation events ( $>0 \mathrm{~mm}$ ) was the highest in Season 5 and the lowest in Season 2.

Soils had on average $80 \mathrm{~kg} \mathrm{~N} \mathrm{ha}^{-1}$ at planting time in the dry season (Season 2), this was $60 \%$ more than the average at the wet Seasons, 1, 4 and 5 (Fig. 1). Soil nitrate- $\mathrm{N}$ varied the most during the extremely wet and dry seasons (Fig. 1). Season 2 also had the highest variation in soil water content expressed as a percent of field capacity between landscape positions (Fig. 1). The depth to the water table varied from 30 to $300 \mathrm{~cm}$ across seasons and treatments (Fig. 1). Season 5 had the highest number of days with temperatures below $10{ }^{\circ} \mathrm{C}$ and Season 2 had the greatest number of days with temperatures above $35^{\circ} \mathrm{C}$ ( 45 and 13 days, respectively; data not shown).

The range of values observed for the static values are reported in Table 1. Some static variables were correlated with one another. We found that the estimated terrain parameters correlated well with soil texture, SOM, and ECa_90 (Figure S4). Soils with high slopes were characterized by low SOM and high sand content whereas high SCA (specific catchment area) was associated with areas of low sand content. As ECa_90 increased, SOM, and SCA increased (Figure S4).

\subsection{Temporal and spatial variability of EONR and yields}

Across the $51 \mathrm{~N}$-trials, the EONR varied from 0 to $260 \mathrm{~kg} \mathrm{~N} \mathrm{ha}^{-1}$ with a mean of $113 \pm 81 \mathrm{~kg} \mathrm{~N}^{-1}$ (Fig. 2). The EONR values were above the 51 trial mean in $90 \%$ of the cases in Season 1, and only $13 \%$ of the cases in Season 5 (Fig. 2). The Yield_NO was below the 51 trial mean value $\left(9.5 \mathrm{Mg} \mathrm{ha}^{-1}\right)$ in all cases in Season 1 and above the mean value in $87 \%$ of the cases in Season 5 (Fig. 2). The mean YEONR was $12.2 \mathrm{Mg} \mathrm{ha}^{-1}$ and its distribution across the 51 trials was skewed to the right. In 3 of the 5 seasons, the spatial variation of EONR and YEONR was higher than their temporal variation (CV of $72 \%$ versus $27 \%$, respectively, Fig. 2). The variability in Yield_N0 was higher across years $(27 \%)$ than within fields (21\%). The YEONR varied less compared to EONR and Yield_NO (Fig. 2).

\subsection{Correlations between EONR, yield and explanatory variables}

During the wettest season (Season 1), highly productive areas (fine texture) had an average EONR of $213 \mathrm{~kg} \mathrm{~N} \mathrm{ha}^{-1}$, whereas low productive areas with 


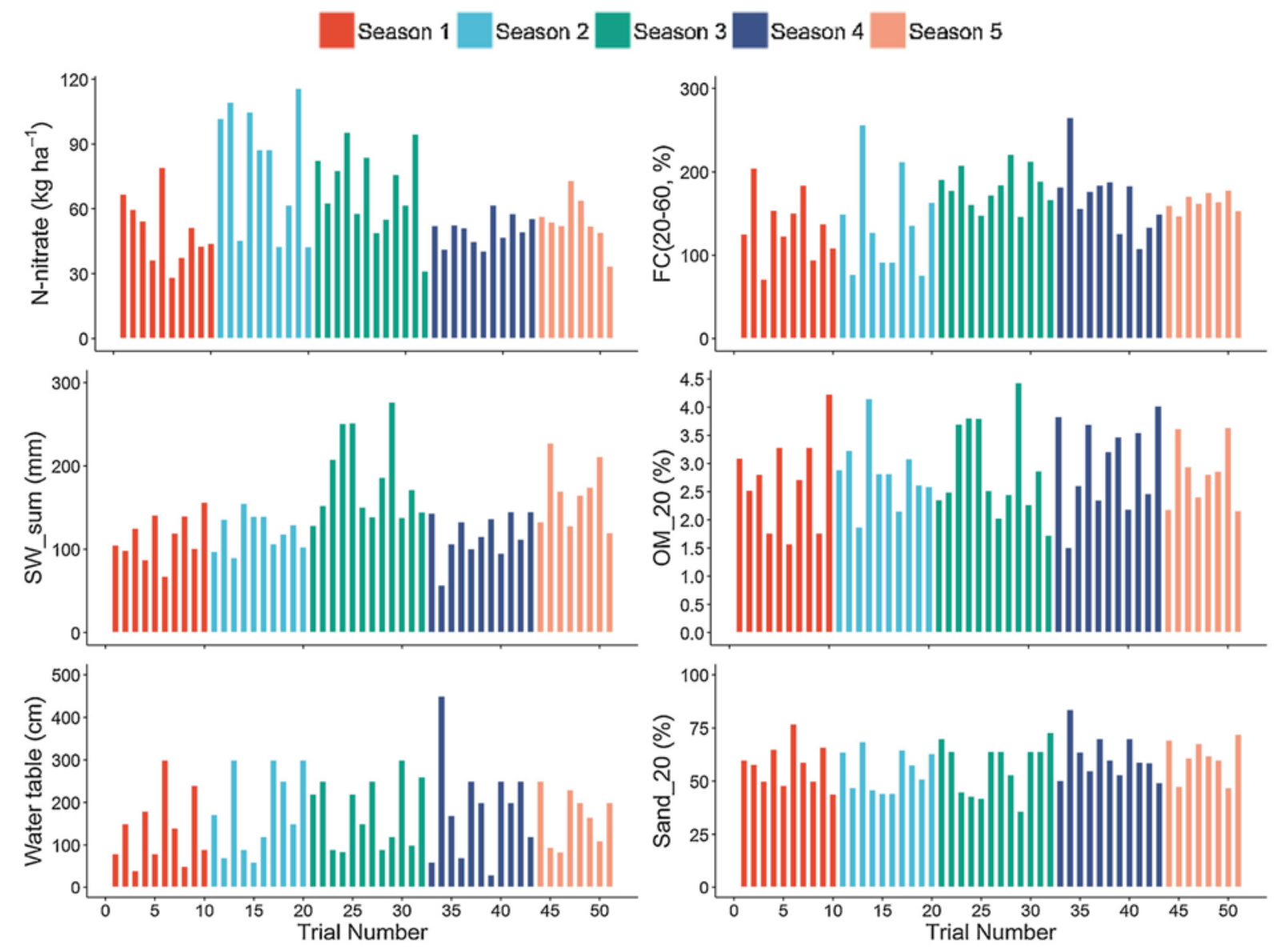

Fig. 1. N-nitrate content from 0 to $60 \mathrm{~cm}$ depth, water as percent of field capacity from 20 to $60 \mathrm{~cm}$ soil depth (FC), soil water from 0 to $60 \mathrm{~cm}$ depth (SW_sum), soil organic matter at $20 \mathrm{~cm}$ depth (OM_20), water table depth at planting, and sand content at $20 \mathrm{~cm}$ depth (Sand_20).

the sandiest soils (sand content>65\%) also had high EONR ( $195 \mathrm{~kg} \mathrm{~N} \mathrm{ha}^{-1}$, Fig. 1 and 2). Field areas with high sand content (> 65\%) and low SOM (< $2.5 \%)$ resulted in high temporal variability in yield and EONR (Fig. 2). We found no relationship between EONR and YEONR (Fig. 3). However, the difference between YEONR and Yield_NO that is the yield response to N was highly correlated with the optimal $N$ rate $\left(R_{A d j}^{2}=0.91\right.$; Fig. 3$)$. In very wet seasons, the yield response to $\mathrm{N}$ was double that of the dry seasons. The differences in yield response to $\mathrm{N}$ were 3-fold higher in fine than coarse textured soils in dry and normal seasons. In general, the EONR, YEONR, and Yield_NO tended to increase as SOM increased and sand content decreased (Figure S5). The EONR and Yield_NO was significantly correlated with precipitation from planting to silking ( $R^{2}$ from 0.20 to 0.57 ), but the magnitude of the response was associated with soil texture and SOM (data not shown). 

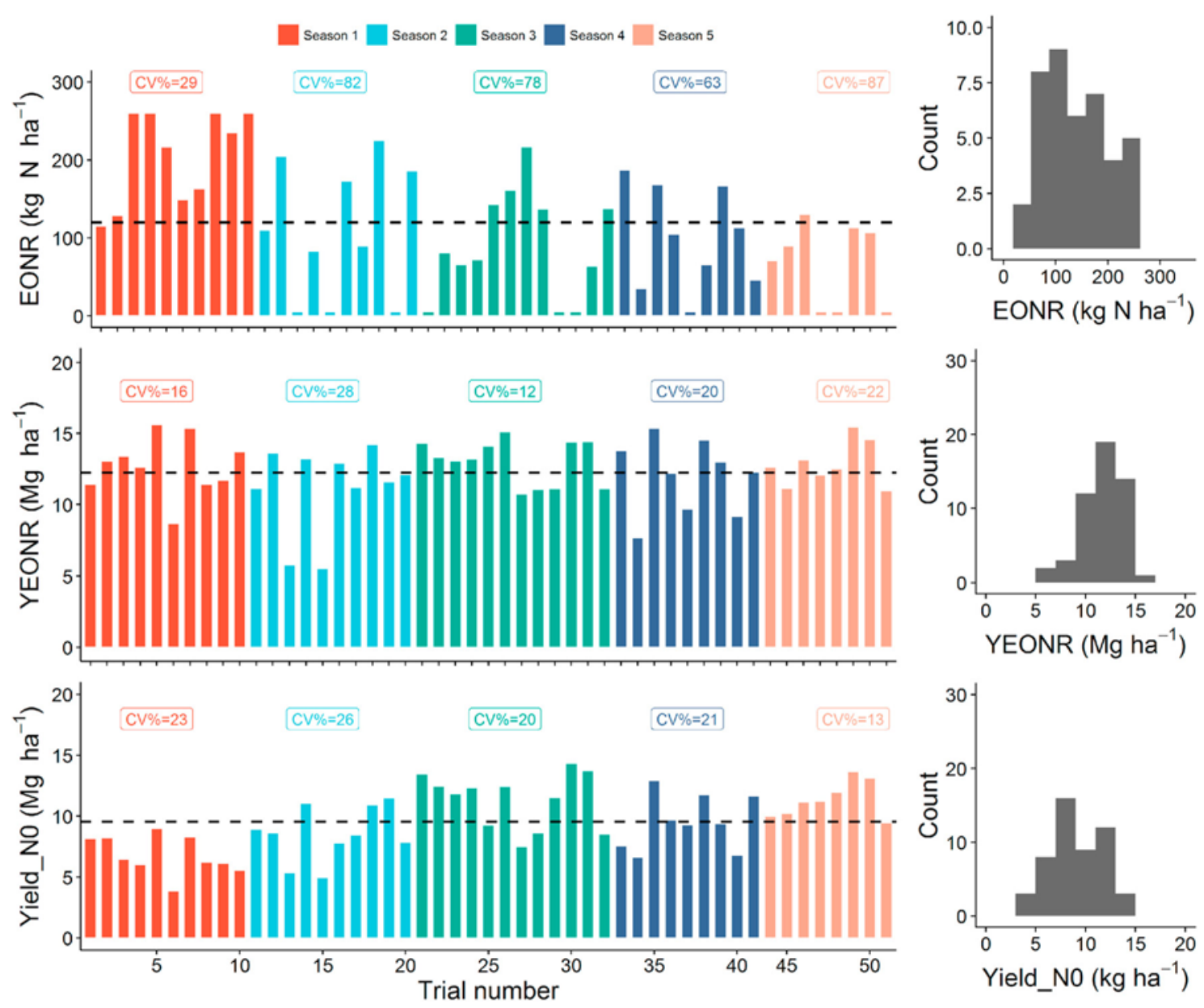

Fig. 2. Observed economic optimum nitrogen rate (EONR), yield at EONR (YEONR), and yield at nitrogen zero (Yield_NO, right panels) and frequency distribution (right panels). Horizontal dashed lines represent the overall mean value. The coefficient of variation (CV\%) for each season is provided.
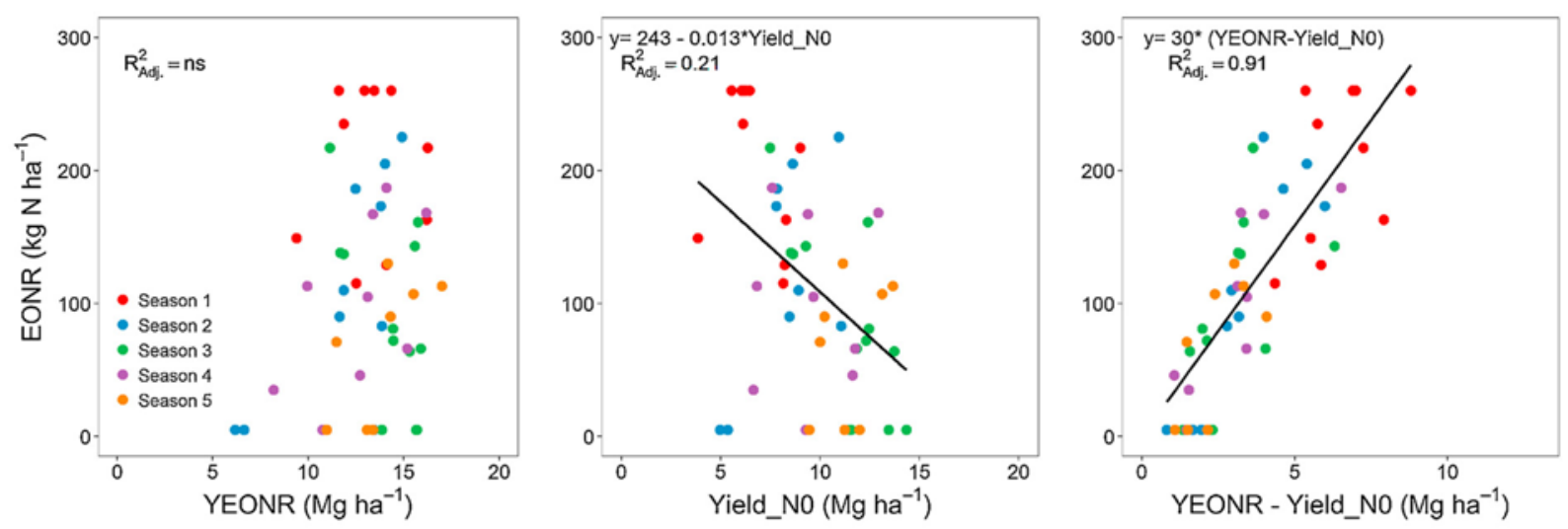

Fig. 3. Economic optimum $N$ rate (EONR) as a function of yield at EONR (YEONR), yield at N zero (Yield_NO), and the difference between YEONR and Yield_NO. 


\subsection{Relative importance of factors and model development}

The variability in EONR and Yield_NO was best explained by dynamic factors while the variability in YEONR was best described by static variables (see $\mathrm{R}_{\mathrm{Adj}}{ }^{2}$ values in Fig. 4). Prediction accuracy substantially increased when we combined dynamic and static variables $\left(R_{\text {Adj }}^{2}>0.60\right.$, Fig. 4).

From a total of 54 static and dynamic variables examined in this study (Table 1), four dynamic variables (precipitation, heat stress, nitrate- $\mathrm{N}$ at planting, residue amount) and one static variable (soil depth) were considered in the EONR full model based on their importance (Table 3). The resulting model explained $61 \%$ of the variability in EONR with a MAE of $39 \mathrm{~kg}$ $\mathrm{N} \mathrm{ha}^{-1}$ (Fig. 2). The number of precipitation events (> $20 \mathrm{~mm}$ ) from planting to silking was found to be the most important variable and heat stress
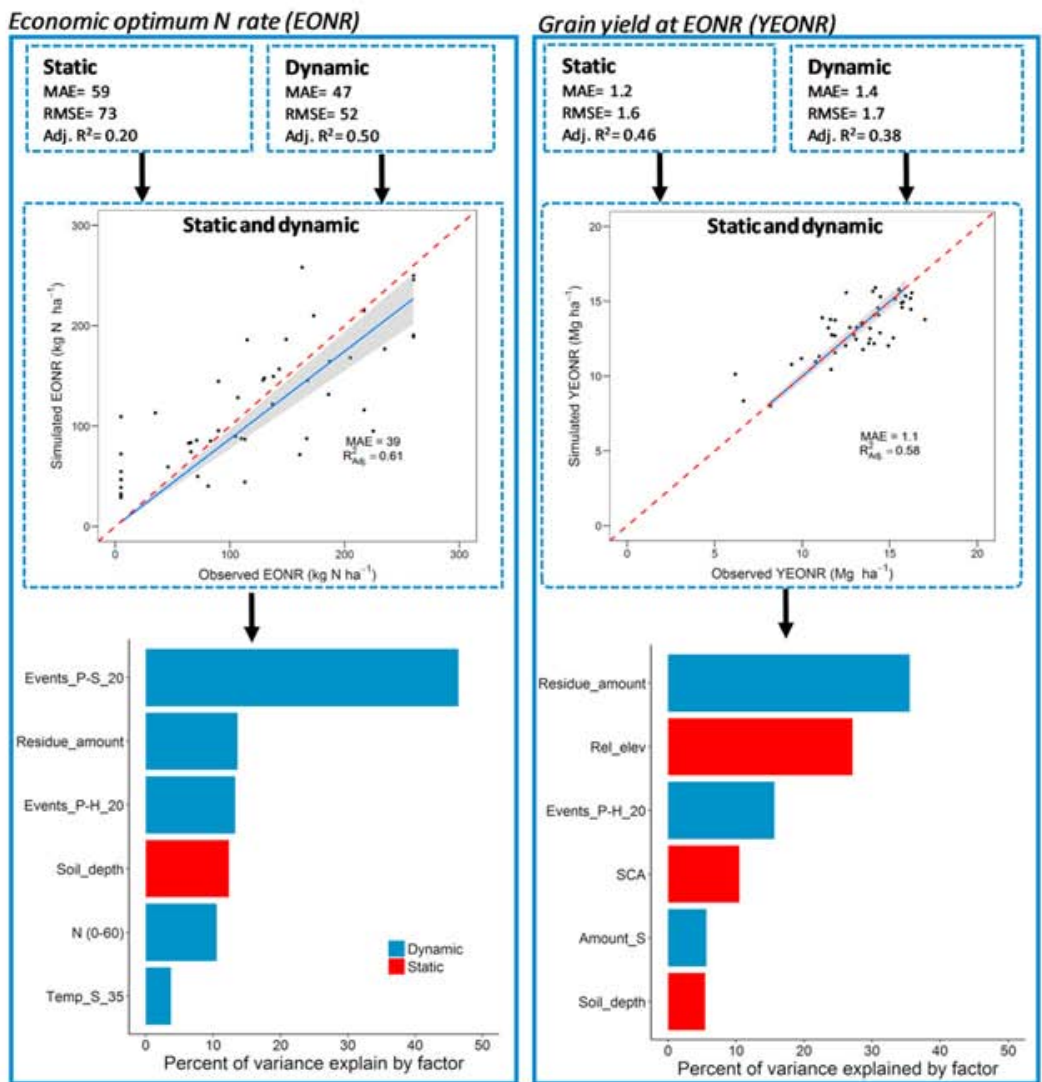

Grain Yield at zero N (Yield NO)

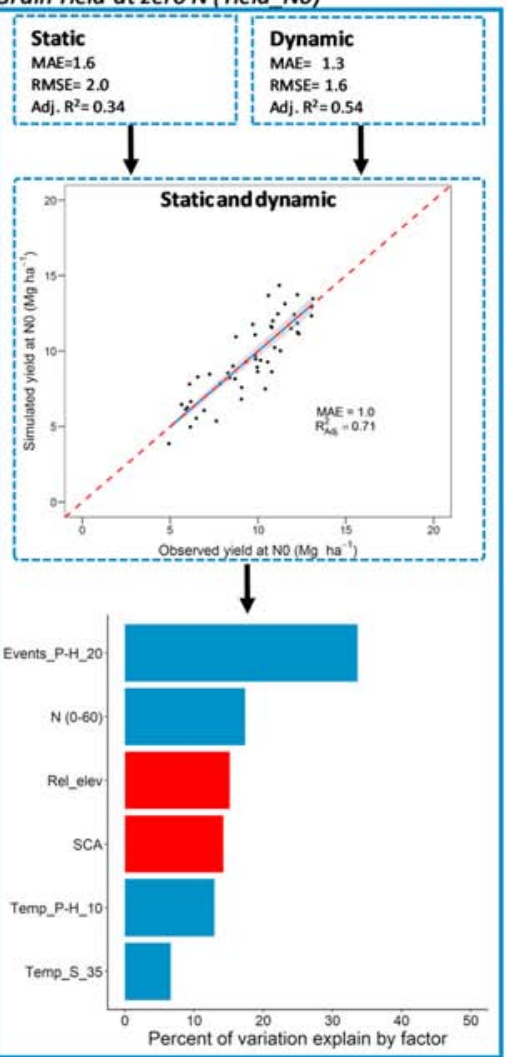

Fig. 4. Diagram of regression models for the economic optimum nitrogen rate (a), yield at the EONR (b), and Yield at NO (c) using static variables, dynamic variables, and a combination of both. Predicted versus observed values for the full models are shown. Diagonal dashed lines are 1:1. The relative importance of static and dynamic variables included in the final model as shown. All acronyms are explained in Table 1. Adjusted coefficient of determination $\left(R^{2}\right)$, mean absolute error (MAE), and root mean square (RMSE) are shown. 
Table 3. Full and reduced regression models for the economic optimum nitrogen rate (EONR; units: $\mathrm{kg} \mathrm{N} \mathrm{ha}^{-1}$ ), yield at EONR (YEONR; $\mathrm{Mg} \mathrm{ha}^{-1}$ ), and yield at nitrogen zero (Yield_NO; Mg $\left.\mathrm{ha}^{-1}\right)$. Acronyms explanation and units are provided in Table 2. An Excel version of these models is provided as supplementary materials.

\begin{tabular}{|c|c|}
\hline Type & Model \\
\hline $\begin{array}{l}\text { Full } \\
\text { (uses data from harvesting of the } \\
\text { previous crop to harvesting of } \\
\text { the next crop) }\end{array}$ & $\begin{array}{l}\text { EONR }=355-163^{*} \text { Soil depth }+22.4^{*} \text { Events_P-S_20 } \\
\quad-10.3^{*} \text { Events_P-H_20 }-1.9^{*} \mathrm{~N}(0-60) \\
\quad+17.1^{*} \text { Temp_S_35 }+0.0196^{*} \text { Residue_amount } \\
\text { YEONR }=18.1-11.6^{*} \text { Rel_elev }-0.18^{*} \text { Events_P-H_20 } \\
\quad-0.008^{*} \mathrm{SCA}+0.013^{*} \text { Amount_S }-3.8^{*} \text { Soil_depth } \\
\quad+0.0058^{*} \text { Residue_amount } \\
\text { Yield_NO }=4.96-0.253^{*} \text { Events_P-H_20 }+0.05^{*} \mathrm{~N}(0-60) \\
\quad-12.56^{*} \text { Rel_elev }-0.008^{*} \mathrm{SCA} \\
-0.56^{*} \text { Temp_S_35 }+0.2^{*} \text { Temp_P-H_10 }\end{array}$ \\
\hline $\begin{array}{l}\text { Reduced } \\
\text { (uses data from harvesting of the previous } \\
\text { crop to planting time of the next crop) }\end{array}$ & 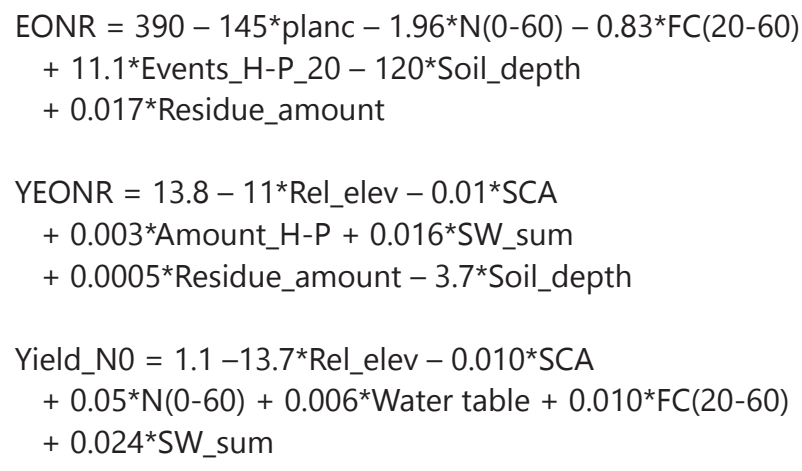 \\
\hline
\end{tabular}

the least important variable in the full EONR model (see variance analysis in Fig. 4). For YEONR and Yield_NO the best single were the residue amount and the number of rain events (> $20 \mathrm{~mm}$ ) from planting to harvest, respectively (Fig. 4; Table 3).

We also re-ran the same analysis with a reduced amount of data (from previous crop harvest to planting of the new crop) and developed three additional models that can be used for forecasting purposes at planting time. The models and parameter values are listed in Table 3. In the reduced models, information on soil water and soil nitrate- $\mathrm{N}$ at planting time became highly important in the EONR and Yield_NO prediction (Fig. 5 and Table 3). Residue amount and Rel_elev were the most important variables for the reduced YEONR model (Fig. 5).

The prediction accuracy of the reduced models was similar for the EONR, YEONR, and Yield_NO $\left(R_{\text {Adj }}{ }^{2}>0.55\right.$, Fig. 5). On average, the full EONR model 


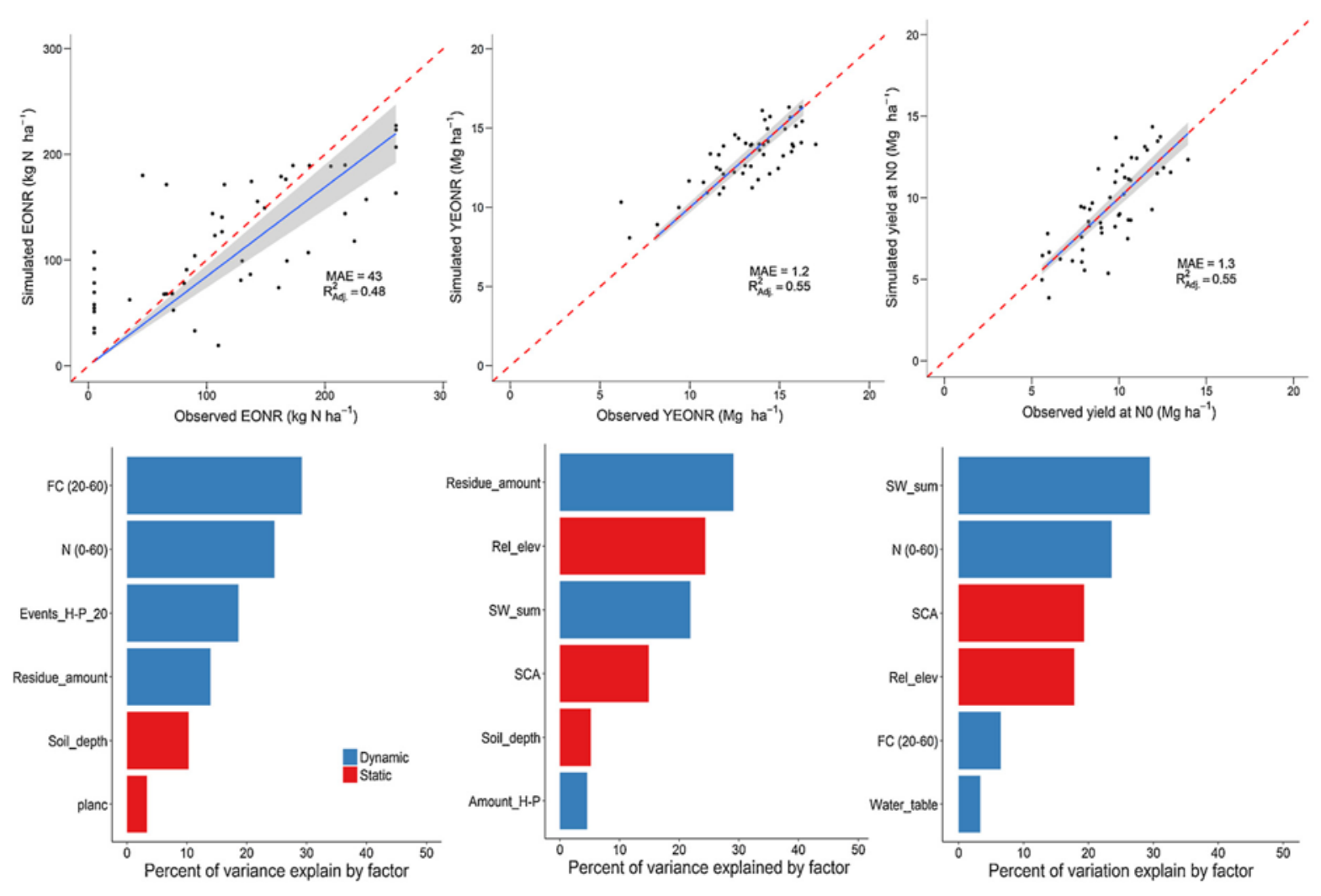

Fig. 5. Relative importance of the static and dynamic variables included in the reduced models. Left panels shows variable included in the EONR model, middle in the YEONR model, and right in the Yield_NO model.

outperformed the reduced models' prediction accuracy by $16 \%$ (Table 2). The full model predicted EONR with a higher MAE in extreme wet and dry Seasons 1 and 2 (MAE $43 \mathrm{~kg} \mathrm{~N} \mathrm{ha}^{-1}$ ). Seasons 1 and 4 had the highest accuracy for Yield_NO and Season 5 had the highest accuracy for EONR (MAE $\sim 29 \mathrm{~kg} \mathrm{~N} \mathrm{ha-1}$, Table 2). The reduced model performed the best for EONR and Yield_NO for the dry Season 2 (MAE $49 \mathrm{~kg} \mathrm{~N} \mathrm{ha}^{-1}$ ) and EONR prediction error was the same as the full model in the wet Season 1(Table 2). Preliminary testing of the EONR models using Season 6 resulted on an average MAE of $52 \mathrm{~kg} \mathrm{~N} \mathrm{ha}^{-1}$. The most accurate EONR predictions were found in landscape position with topsoil sand content $<65 \%$ and SOM $>2.5 \%$ (absolute difference between observed and predicted values was on average $17 \mathrm{~kg} \mathrm{~N} \mathrm{ha}^{-1}$ ). The least accurate EONR predictions were for a sandy hill site with $\mathrm{OM}<2 \%$. Regarding YEONR prediction, the MAE ranged from 1 to 1.9 $\mathrm{Mg} \mathrm{ha}^{-1}$ in most cases (Figure S7). 


\section{Discussion}

\subsection{The economic optimum $\mathbf{N}$ rate in Argentina}

Findings from this $51 \mathrm{~N}$ trial study suggest that there is potential for yield increases in Argentina by improving $\mathrm{N}$ management. In $70 \%$ of our $\mathrm{N}$ trials, the EONR was higher than the regional average $\mathrm{N}$ application rate currently used in Argentina (Bolsa de Cereales, 2018) and the average YEONR was $4 \mathrm{Mg} \mathrm{ha}^{-1}$ higher than the regional average corn yield (Andrade and Satorre, 2015; Fig. 2). However, increasing $N$ fertilization rate adds a significant economic risk that most producers in this region were not willing to accept because of the year-to-year variability in EONR (Puntel et al., 2017). Here we not only quantified the variability in EONR (Fig. 2)-a critical information that was previously missing for this region-but more importantly, we developed predictive models that account for weather and soil variability to aid producer's $\mathrm{N}$ decision-making.

\subsection{Implications of the developed models}

The developed models are field specific and fill the gap between very simple EONR prediction tools (one input) and more complex $\mathrm{N}$ tools such as simulations models that require several input parameters (Basso and Liu, 2018). In a recent review by Morris et al. (2018) on N recommendation tools, it was noticeable that all current approaches used are either too simple or too complex. Our models integrate key static and dynamic variables, reflecting existing knowledge on factors affecting EONR (e.g. precipitation distribution), and has tremendous potential in view of increasing data availability in agriculture. While complex simulation models have already proven to be well-suited to support $\mathrm{N}$ decisions in specific fields (Basso et al., 2011) their utilization is still low because of challenges related to site-specific model calibration, large number of input requirements, and social difficulties in delivering model-based results to stakeholders (Salo et al., 2016; Banger et al., 2017; He et al., 2017). Our tool uses fewer inputs than a simulation model and is easier to deploy across a broad geographic area. Compared to simple $\mathrm{N}$ recommendation tools such as the yield goal approach, soil nitrate- $\mathrm{N}$ test, or use of the long-term average EONR, our model accounts for spatial and temporal variability and thus is well suited for application in precision agriculture.

This study expands earlier efforts to predict corn's EONR using more than one explanatory variable in Argentina (Gregoret et al., 2011; Coyos et al., 2018) and in the USA (Qin et al., 2018). Gregoret et al. (2011) considered total soil $\mathrm{N}$ and available water, Coyos et al. (2018) soil N, planting time, and 
soil type, while Qin et al. (2018) considered soil water holding capacity and minimum groundwater table depth. Our model has six explanatory variables for EONR, which resulted from statistical analysis of their importance (Fig. 4). In agreement with Gregoret et al. (2006), precipitation was one of the most important variables in our model. Importantly, our analysis revealed other important factors such as soil depth or residue amount (Table 3) have been ignored in previous $\mathrm{N}$ tools. Thus, beyond predictability of EONR, this study also offers guidance on future research investment and data collection from $\mathrm{N}$ trials.

Compared to complex simulation models (Liu et al., 2013; Puntel et al., 2016; Sela et al., 2017; Yang et al., 2014), the prediction error of the full EONR model is similar (MAE 30-40 kg N ha-1). The reduced EONR model that was designed for $\mathrm{N}$ forecasting at planting time, had $16 \%$ less predictive accuracy than the full model but this was expected given the fewer inputs are utilized. Preliminary testing showed that both full and reduced models gave reasonable results (Figure S7), but further testing is needed across multiple environments to increase confidence. Here we developed the concept and provided a list of important parameters to be measured in future trials. As new data becomes available the proposed models could be further improved and expanded. The developed models/framework have future potential as they can provide farmers with flexibility to adjust their $\mathrm{N}$ rates for their specific fields given local weather conditions, soil properties, and management that differ from field to field.

In the future, some labor-intensive input parameters that are currently part of our models could be further simplified (Table 2). For example, the amount of residue $(\mathrm{kg} / \mathrm{ha}$ ) can be replaced by categorical classes such as very low, low, normal, high and very high amounts. We tested this concept (data not shown) and we found that the EONR prediction accuracy remained at similar levels compared to models listed in Table 2. Similarly, the initial soil moisture at planting could be replaced by classes. This approach may enhance deployment of the models across environments but more work is needed to develop and test it. Lastly, other variables such as plant density (Carlone and Russell, 1987) or genotype (Gambin et al., 2016) that are known to influence EONR could be incorporated into the models. Grain and fertilizer prices could also be added towards developing a more flexible $\mathrm{N}$ decision tool.

During model development we faced several challenges that should be considered in future studies. We found that the relative importance of static variables selected for inclusion in the models changed based on which dynamic variables were considered. This is evident by the fact that different variables were found to be important and thus included in the full and reduced models. For example, when we removed data on soil texture and 
precipitation distribution, we found that ECa and terrain parameters became more important in the models (data not shown). Lastly, some of the factors accounted for in our models could influence yield in a non-linear manner, while in our models we considered the relationships to be linear.

\subsection{Analysis of factors affecting the EONR and yields}

Our study provides for the first time a comparative analysis of static and dynamic factors influencing EONR, YEONR and Yield_NO that was missing from the literature. From a list of 54 factors, statistical analysis identified 14 to be the most important variables for EONR, YEONR and Yield_NO predictions in this region (Figs. 4 and 5). It is interesting to note that yield of the previous crop, currently used to develop management zones and $\mathrm{N}$ recommendations (Kersebaum et al., 2002), was not an important factor. In contrast, we found residue amount to explain significant portions of the YEONR and EONR variability (Figs. 4 and 5). Therefore future research should focus more on determining residue amount and decomposition dynamics rather than on precisely estimating past crop yields to inform future $\mathrm{N}$ recommendations.

Our results suggest that variable $\mathrm{N}$ rate recommendations based on previous yields and static variables such as texture and SOM could fail when weather conditions are wet or extremely wet, which agrees with other studies such as Cerrato and Blackmer, 1991) and Vanotti and Bundy, 1994a,b. For example, the yield response to $\mathrm{N}$ was almost double in wet compared to dry seasons (Fig. 3), this is in agreement with previous studies (Kyveryga et al., 2009). The yield response to $\mathrm{N}$ was 3 -fold higher in fine than coarse textured soils in dry and normal seasons, similar to Shahandeh et al. (2011). These examples strengthen the need for having a $\mathrm{N}$ recommendation tool that combines temporal and spatial variability.

In this study, seasons 4 and 5 had high yields ( $\left.12 \mathrm{Mg} \mathrm{ha}^{-1}\right)$ with relatively low EONR ( $70 \mathrm{~kg} \mathrm{~N} \mathrm{ha}^{-1}$; Fig. 3) and thus it is important to understand the cause. Analysis of different factors indicated that the reason was the distribution of precipitation within these two seasons: high frequency of small rain events and low frequency of extreme rain events (> $20 \mathrm{~mm}$ ) where $\mathrm{N}$ losses are likely to occur (Davis et al., 2000; Rimski-Korsakov et al., 2004). The high frequency of small rain events in Season 4 and 5 resulted in higher Yield $\mathrm{N} 0$, and reduced the yield response to $\mathrm{N}$, therefore, decreasing the EONR (Fig. 3; Sogbedji et al., 2001).

Among different ways of analyzing precipitation data, we found that the number of days with precipitation greater than $20 \mathrm{~mm}$ from planting to silking, and from planting to harvest to be very good predictors of the EONR and Yield_NO variability in the full model (Fig. 4). Although there is a similarity between these two variables (same variable name but different 
time-periods), our statistical analysis revealed no significant auto-correlation. In the reduced model, precipitation events prior to planting, and soil moisture relative to field capacity at planting, were the most important variables.

Water table depth was a significant factor in the reduced Yield_NO model (Fig. 5) but not in the other models. Presumably this is because of its relation to precipitation and landscape position (Gleeson et al., 2011). With the difficulty in measuring water tables, use of elevation position may be a good alternative because of the correlation between these variables (Fig. 4; Nosetto et al., 2009). Interestingly, relative elevation (Table 1) was one of the most important explanatory variables in both YEONR and Yield_NO models. Other static factors such as SCA, pcurv, and slope are relevant in regression models, mainly because of their control on water availability (Van Ittersum et al., 2002), N dynamics, and thus yield (Kaspar et al., 2004; Kravchenko and Bullock, 2000).

Neither soil nitrate- $\mathrm{N}$ at planting nor the YEONR were good single predictors of the EONR (Fig. 3 to 6), this is in line with literature from rainfed regions (Lory and Scharf, 2003; Sawyer et al., 2006; Vanotti and Bundy, $1994 a, b)$. In contrast, when soil nitrate information was combined with other static and dynamic factors, it proved to be a very important factor in the full Yield_NO model and in the reduced EONR model (Figs. 4 and 5). This further justifies our previous statement for the need to combined different approaches/data inputs towards improving predictability of EONR (Kay et al., 2006f).

Finally, we found a significant relationship between the difference of YEONR and Yield_NO and the EONR $\left(R_{\text {Adj }}{ }^{2}=0.92 ;\right.$ Fig. 3$)$. This relationship is interesting because it offers an alternative way to estimate EONR using information on optimum and minimum yield. In a previous study (Puntel et al., 2016, 2018), we found that the APSIM crop model predicted optimum and minimum yields more accurately than EONR. This relationship may help in the way we currently calculate EONR via crop models. Furthermore, use of this relationship will decrease the number of crop model simulations required to calculate the EONR (from 5 to 30 simulations to only two; Puntel et al., 2016).

\section{Conclusions}

Our approach provides a new avenue to integrating and analyzing various datasets towards development of data-driven recommendations to growers. These multifaceted datatypes are likely to become readily available in the near future through advances in technology. The new $\mathrm{N}$ models developed and presented in this study fill the gap between simple and complex 
$\mathrm{N}$ tools. The prediction accuracy was satisfactory but further testing across environments is needed to increase confidence. Beyond predictability, this study also offers guidance on which variables to be measured in future $\mathrm{N}$ trials based on their importance.

Acknowledgments - This work was part of the Agriculture and Food Research Initiative Hatch project No. 1004346 and partially funded by the lowa State University Plant Sciences Institute. We also thank the support of the farm's owners where the trials were established, Doña Norma Pedemonte, German Molea, and Juan Carlos Pagani. Special thanks to Dr. Philip Dixon and the PhD student Kathleen Rey from lowa State University for their contribution in the statistical analysis and to Dr. Martinez-Feria for his helpful comments. Thanks also to Geronimo and Alcidez Gonzalez for hand harvesting the corn trials and the lab technicians at Clarion Soil Testing Lab for analyzing the soil samples.

Appendix A. Supplementary data - Supplementary material follows the References; and the Excel model is attached to the main repository record for this article.

\section{References}

Abendroth, L.J., Elmore, R.W., Boyer, M.J., Marlay, S.K., 2011. "Corn Growth and Development." Publ. PMR 1009. lowa State University Extension and Outreach, Ames, IA.

Albarenque, S.M., Basso, B., Caviglia, O.P., Melchiori, R.J.M., 2016. Spatio-temporal nitrogen fertilizer response in maize: field study and modeling approach.

Agron. J. 108 (5), 2110-2122.

Alexandratos, N., Bruinsma, J., 2012. World agriculture towards 2030/2050. Land Use Policy 20 (4), 375.

AMIS, 2018. Agricultural Market Information System. Retrieved from http://www. amisoutlook.org/amis-about/en/

Andrade, J.F., Satorre, E.H., 2015. Single and double crop systems in the argentine pampas: environmental determinants of annual grain yield. Field Crops Res. 177, 135-147.

Andrade, F.H., Uhart, S.A., Frugone, M., 1993. Intercepted radiation at flowering and kernel number in maize: shade versus plant density effects. Crop Sci. 33, 482-485.

Andraski, T.W., Bundy, L.G., Brye, K.R., 2000. Crop management and corn nitrogen rate effects on nitrate leaching. J. Environ. Qual. 29, 1095-1103.

Aparicio, V., Costa, J.L., Zamora, M., 2008. Nitrate leaching assessment in a longterm experiment under supplementary irrigation in humid Argentina. Agric. Water Manag. 95 (12), 1361-1372.

Archontoulis, Sotirios V., Miguez, Fernando E., 2015. Nonlinear regression models and applications in agricultural research. Agron. J. 107 (2), 786-798. 
Baethgen, W.E., Taylor, D.B., Alley, M.M., 1989. Quadratic programming method for determining optimum nitrogen rate for winter wheat during tillering. Agron. J. 81, 557-559.

Banger, K., Yuan, M., Wang, J., Nafziger, E.D., Pittelkow, C.M., 2017. A vision for incorporating environmental effects into nitrogen management decision support tools for U.S. Maize production. Front. Plant Sci. 8, 1270.

Basso, B., Liu, L., 2018. Seasonal crop yield forecast: methods, applications, and accuracies. Advances in Agronomy. https://doi.org/10.1016/ bs.agron.2018.11.002

Basso, B., Ritchie, J.T., Pierce, F.J., Braga, R.P., 2001. Spatial validation of crop models for precision agriculture. Agric. Syst. 68.

Basso, B., Ritchie, J.T., Cammarano, D., Sartori, L., 2011. A strategic and tactical management approach to select optimal $\mathrm{N}$ fertilizer rates for wheat in a spatially variable field. Eur. J. Agron. 35 (4), 215-222.

Basso, B., Cammarano, D., Fiorentino, C., Ritchie, J.T., 2013. Wheat yield response to spatially variable nitrogen fertilizer in Mediterranean environment. Eur. J. Agron. 51, 65-70.

Brevik, E.C., Fenton, T.E., Lazari, A., 2006. Soil electrical conductivity as a function of soil water content and implications for soil mapping. Precis. Agric. 7 (6), 393-404.

Bolsa de Cereales, 2018. Relevamiento de Tecnologia Agricola Aplicada de la Bolsa de Cereales. Informe ReTAA No7. http://www.bolsadecereales.com/retaa

Bullock, D.G., Bullock, D.S., 1994. Quadratic and quadratic-plus-plateau models for predicting optimal nitrogen rate of corn: a comparison. Agron. J. 86 (1), 191-195.

Cabrera, M.L., Kissel, D.E., Vigil, M.F., 2005. Nitrogen mineralization from organic residues: research opportunities. J. Environ. Qual. 34, 75-79.

Carlone, M.R., Russell, W.A., 1987. Response to plant densities and nitrogen levels for four maize cultivars from different eras of breeding 1. Crop Sci. 27 (3), 465-470.

Cerrato, M.E., Blackmer, A.M., 1990. Comparison of models for describing; corn yield response to nitrogen fertilizer. Agron. J. 82 (1), 138-143.

Cerrato, M.E., Blackmer, A.M., 1991. Relationships between leaf nitrogen concentrations and the nitrogen status of corn. J. Prod. Agric. 4 (4), 525-531.

Chang, J., Clay, D., Carlson, D.E., Reese, C.G., Clay, C.L., Ellsbury, S.A., M. M, 2004. Defining yield goals and management zones to minimize yield and nitrogen and phosphorus fertilizer recommendation errors. Agron. J. 3, 825-831.

Coyos, T., Borrás, L., Gambin, B.L., 2018. Site-specific covariates affecting yield response to nitrogen of late-sown maize in Central Argentina. Agron. J. 110 (4), 1544-1553.

Davis, C.W., 1916. Studies on the phenoldisulphonic acid method for determining nitrates in soils. J. Indus. Eng. Chem. 9, 290-295.

Davis, D.M., Gowda, P.H., Mulla, D.J., Randall, G.W., 2000. Modeling Nitrate Nitrogen Leaching in Response to Nitrogen Fertilizer Rate and Tile Drain Depth or Spacing for Southern Minnesota, USA. J. Environ. Qual. 29, 1568-1581.

Dhital, S., Raun, W.R., 2016. Variability in optimum nitrogen rates for maize. Agron. J. 108 (6), 2165-2173. 
Dinnes, D.L., Karlen, D.L., Jaynes, D.B., Kaspar, T.C., Hatfield, J.L., 2002. Review and interpretation: Nitrogen management strategies to reduce nitrate leaching in tile-drained midwestern soils. Agron. J. 94 (1), 153-171.

Edreira, J.R., Otegui, M.E., 2013. Heat stress in temperate and tropical maize hybrids: a novel approach for assessing sources of kernel loss in field conditions. Field Crops Res. 142, 58-67.

ESRI, 2018. ArcGIS Desktop: Release 10.6.1 Redlands. Environmental Systems Research Institute., CA.

Ferrari, M., Castellarin, J., Sainz Rozas, H., Vivas, H., Melchiori, R., y Gudelj, V., 2010. Evaluación de métodos de diagnóstico de fertilidad nitrogenada para el cultivo de trigo en la región pampeana. Inform. Agron. 46, 10-12 IPNI.

Gambin, B.L., Coyos, T., Di Mauro, G., Borrás, L., Garibaldi, L.A., 2016. Exploring genotype, management, and environmental variables influencing grain yield of late-sown maize in central Argentina. Agric. Syst. 146, 11-19.

Gleeson, T., Marklund, L., Smith, L., Manning, A.H., 2011. Classifying the water table at regional to continental scales. Geophys. Res. Lett. 38 (5), 1-6.

Gregoret, M.C., Dardanelli, J., Bongiovanni, R., Díaz-Zorita, M., 2006. Modelo de respuesta sitio-específica del maíz al nitrógeno y agua edáfica en un haplustol. Ciencia del Suelo 24 (2), 147-159.

Gregoret, M.C., Díaz-Zorita, M., Dardanelli, J., Bongiovanni, R., 2011. Regional model for nitrogen fertilization of site-specific rainfed corn in haplustolls of the central Pampas, Argentina. Precis. Agric. 12, 831-849. https://doi.org/10.1007/

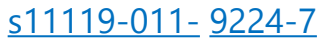

Gromping, Ulrike, 2006. Relative Importance for Linear Regression in R : The Package Relaimpo 171.

He, D., Wang, E., Wang, J., Robertson, M.J., 2017. Data requirement for effective calibration of process-based crop models. Agric. For. Meteorol. 234, 136-148.

Heiniger, R.W., McBride, R.G., Clay, D.E., 2003. Using soil electrical conductivity to improve nutrient management. Agron. J. 95 (3), 508-519.

Hergert, G.W., Ferguson, R.B., Shapiro, C.A., Penas, E.J., Anderson, F.B., 1995. Classical statistical and geostatistical analysis of soil nitrate- $N$ spatial variability. In Site-specific Management for Agricultural Systems, pp. 175-186 American Society of Agronomy, Crop Science Society of America, Soil Science Society of America.

Jaynes, Dan B., 2011. Confidence bands for measured economically optimal nitrogen rates. Precis. Agric. 12 (2), 196-213.

Jaynes, D.B., 2012. Changes in Yield and Nitrate Losses from Using Drainage Water Management in Central lowa, United States. J. Soil Water Conserv. 67 (6), 485-494.

Kaspar, T.C., Kaspar, T.C., Pulido, D.J., Fenton, T.E., Colvin, T.S., Karlen, D.L., Jaynes, D.B., Meek, D.W., 2004. Relationship of corn and soybean yield to soil and terrain properties. Agron. J. 96 (3), 700-709.

Kay, B.D., Mahboubi, A.A., Beauchamp, E.G., Dharmakeerthi, R.S., 2006. Integrating Soil and Weather Data to Describe Variability in Plant Available Nitrogen. Soil Sci. Soc. Am. J. 70 (4), 1210-1221.

Kersebaum, K.C., Lorenz, K., Reuter, H.I., Wendroth, O., Ahuja, L.R., 2002. Modelling crop growth and nitrogen dynamics for advisory purposes regarding spatial 
variability. Agricultural System Models in Field Research and Technology Transfer. CRC Press, pp. 234-257.

King, J.A., Dampney, P.M.R., Lark, R.M., Wheeler, H.C., Bradley, R.I., Mayr, T.R., 2005. Mapping potential crop management zones within fields: use of yield-map series and patterns of soil physical properties identified by electromagnetic induction sensing. Precis. Agric. 6 (2), 167-181.

Kitchen, N.R., Drummond, S.T., Lund, E.D., Sudduth, K.A., Buchleiter, G.W., 2003. Soil electrical conductivity and topography related to yield for three contrasting soil-crop systems. Agron. J. 95, 483-495.

Kitchen, N.R., Sudduth, K.A., Myers, D.B., Drummond, S.T., Hong, S.Y., 2005. Delineating productivity zones on claypan soil fields using apparent soil electrical conductivity. Comput. Electron. Agric. 46 (1-3), 285-308.

Kravchenko, A.N., Bullock, D.G., 2000. Correlation of corn and soybean grain yield with topography and soil properties. Agron. J. 92 (1), 75-83.

Kyveryga, P.M., Blackmer, A.M., Zhang, J., 2009. Characterizing and classifying variability in corn yield response to nitrogen fertilization on subfield and field scales. Agron. J. 101, 269-277. https://doi.org/10.2134/agronj2008.0168.

LECO, 2008. Organic application notes. LECO, St. Joseph, MI. Available at http:// www.leco.com/resources/application notes/OrganicCHNSOappNoteForm.html [accessed 18 Feb. 2008; verified 16 Dec. 2011].

Liu, S., Yang, J.Y., Zhang, X.Y., Drury, C.F., Reynolds, W.D., Hoogenboom, G., 2013. Modelling crop yield, soil water content and soil temperature for a soybeanmaize rotation under conventional and conservation tillage systems in Northeast China. Agric. Water Manag. 123, 32-44.

Lory, J.A., Scharf, P.C., 2003. Yield goal versus Delta yield for predicting fertilizer nitrogen need in corn. Agron. J. 95 (4), 994-999.

Mamo, M., Malzer, G.L., Mulla, D.J., Huggins, D.R., Strock, J., 2003. Spatial and temporal variation in economically optimum nitrogen rate for corn. Agron. J. 95 (4), 958-964.

Mejia, M.N., Madramootoo, C.A., Broughton, R.S., 2000. Influence of water table management on corn and soybean yields. Agr. Water Manage 46, 73-89.

Melchiori, R.J., Novelli, L.E., Gregorutti, V.C., Caviglia, O.P., 2014. Stover quality and soil organic carbon in long-term nitrogen-fertilized maize. Agron. J. 106 (5), 1709-1716.

Miller, B.A., 2014. Semantic calibration of digital terrain analysis. Cartogr. Geogr. Inf. Sci. J. 41, 166-176. https://doi.org/10.1080/15230406.2014.883488.

Moore, I.D., Grayson, R.B., 1991. Terrain based prediction of runoff with vector elevation data. Wat. Resour. Res. 27, 1177-1191.

Morris, T.F., Murrell, T.S., Beegle, D.B., Camberato, J.J., Ferguson, R.B., Grove, J., Ketterings, Q., Kyveryga, P.M., Laboski, C.A.M., McGrath, J.M., Meisinger, J.J., Melkonian, J., Moebius-Clune, B., Nafziger, E.D., Osmond, D., Sawyer, J.E., Scharf, P.C., Smith, W., Spargo, J.T., van Es, H.M., Yang, H., 2018. Strengths and limitations of nitrogen rate recommendations for corn and opportunities for improvement. Agron. J. 110, 1-137.

Nosetto, M.D., Jobbágy, E.G., Jackson, R.B., Sznaider, G.A., 2009. Reciprocal influence of crops and shallow ground water in sandy landscapes of the inland pampas. Field Crops Res. 113 (2), 138-148. 
Ordóñez, R.A., Savin, R., Cossani, C.M., Slafer, G.A., 2015. Yield response to heat stress as affected by nitrogen availability in maize. Field Crops Res. 183, 184-203.

Pagani, A., Echeverria, H.E., Sainz Rozas, H., Barbieri, P.A., 2008. Dosis óptima económica de nitrógeno en maíz bajo siembra directa en el Sudeste bonaerense. Ciencia del Suelo 26 (2), 179-188.

Peralta, N.R., Costa, J.L., Balzarini, M., Angelini, H., 2013. Delineation of management zones with measurements of soil apparent electrical conductivity in the southeastern pampas. Can. J. Soil Sci. 93 (2), 205-218.

Puntel, L.A., Sawyer, J.E., Barker, D.W., Dietzel, R., Poffenbarger, H., Castellano, M.J., Moore, K.J., Thorburn, P., Archontoulis, S.V., 2016. Modeling long-term corn yield response to nitrogen rate and crop rotation. Front. Plant Sci. 7 November 2016.

Puntel, L., Archontoulis, S.A., Pagani, A., 2017. Site-Specific Nitrogen Response Functions for Maize in Argentina." in American Society of Agronomy. Tampa, FL. Retrieved. https://scisoc.confex.com/crops/2017am/webprogram/Paper107787.html

Puntel, L.A., Sawyer, J.E., Barker, D.W., Thorburn, P.J., Castellano, M.J., Moore, K.J., VanLoocke, A., Heaton, E.A., Archontoulis, S.V., 2018. A systems modeling approach to forecast corn economic optimum nitrogen rate. Front. Plant Sci. 9.

Qin, Z., Myers, D.B., Ransom, C.J., Kitchen, N.R., Liang, Sang-Zi, Camberato, J.J., Carter, P.R., Ferguson, R.B., Fernandez, F.G., Franzen, D.W., Laboski, C.A.M., Malone, B.D., Nafziger, E.D., Sawyer, J.E., Shanahan, J.F., 2018. Application of Machine Learning Methodologies for Predicting Corn Economic Optimal Nitrogen Rate. Agron. J in press.

R Core Team, 2018. R: A Language and Environment for Statistical Computing. Retrieved (http://www.r-project.org/).. .

Rimski-Korsakov, H., Rubio, G., Lavado, R.S., 2004. Potential Nitrate Losses under Different Agricultural Practices in the Pampas Region, Argentina. Agric. Water Manag. 65 (2), 83-94.

Ruiz, R., Satorre, E., Maddoni, G., Carcova, J., Otegui, M., 2001. Umbrales de decisión para la fertilización nitrogenada en maíz. VII Congreso Nacional de Maíz.

Sainz Rozas, H., Echeverría, H., Studdert, G., Dominguez, G., 2000. Evaluation of the presidedress soil nitrogen test for no-tillage maize fertilized at planting. Agron. J. 92 (6), 1176-1183.

Sainz Rozas, H., Echeverría, H., Herfurt, E., Studdert, E., 2001. Nitrato en la base del tallo de maíz. II. Diagnóstico de la nutrición nitrogenada. Ciencia del Suelo 19 (2), 125-135.

Salo, T.J., Palosuo, T., Kersebaum, K.C., Nendel, C., Angulo, C., Ewert, F., Bindi, M., Calanca, P., Klein, T., Moriondo, M., Ferrise, R., 2016. Comparing the performance of $11 \mathrm{crop}$ simulation models in predicting yield response to nitrogen fertilization. J. Agric. Sci. 154 (7), 1218-1240.

Satorre, E., Mercau, J., 2001. Bases de decisión para la fertilización nitrogenada en maíz. Informe Convenio AACREA-FAUBA.

Sawyer, J., Nafziger, E., Randall, G., Bundy, L., Rehm, G., Joern, B., 2006. Concepts and Rationale for Regional Nitrogen Rate Guidelines for Corn Concepts and Rationale for Regional Nitrogen Rate Guidelines for Corn. Iowa State University, University Extension (April 2006). pp. 1-28. 
Saxton, K.E., Rawls, W.J., 2006. Soil water characteristic estimates by texture and organic matter for hydrologic solutions. Soil Sci. Soc. Am. J. 70 (5), 1569-1578.

Scharf, Peter C., 2015. "Managing Nitrogen" Managing Nitrogen in Crop Production. American Society of Agronomy Inc., USA, pp. 25-76.

Scharf, P.C., Lory, J.A., 2006. Best Management Practices for Nitrogen Fertilizer in Missouri. University of Missouri Extension. http://plantsci.missouri.edu/ nutrientmanagement/nitrogen/practices.htm [last accessed 19 March 2013].

Sela, S., van Es, H.M., Moebius-Clune, B.N., Marjerison, R., Moebius-Clune, D., Schindelbeck, R., 2017. Dynamic model improves agronomic and environmental outcomes for maize nitrogen management over static approach. J. Environ. Qual. 46 (2), 311.

Shahandeh, H., Wright, A.L., Hons, F.M., 2011. Use of soil nitrogen parameters and texture for spatially-variable nitrogen fertilization. Precis. Agric. 12 (1), 146-163.

Shaner, D.L., Khosla, R., Brodahl, M.K., Buchleiter, G.W., Farahani, H.J., 2008. How Well Does Zone Sampling Based on Soil Electrical Conductivity Maps Represent Soil Variability? Agron. J. 100 (5), 1472-1480.

Shapiro, C.A., Ferguson, R.B., Hergert, G.W., Wortmann, C.S., Walters, D.T., 2008. Fertilizer Suggestions for Corn. EC117, Nebraska Extension, Lincoln, NE, pp. 1-6. Sogbedji, J., Sogbedji, J.M., van ES, H.M., Klausner, S.D., Bouldin, D.R., Cox, W.J., 2001. Spatial and temporal processes affecting nitrogen availability at the landscape scale. Soil Tillage Res. 58 (3-4), 233-244.

Soil Survey Staff, 2014. Illustrated Guide to Soil Taxonomy. U.S. Department of Agriculture, Natural Resources Conservation Service. National Soil Survey Center, Lincoln, Nebraska.

Stanford, G., Legg, J., Smith, S., 1973. Soil nitrogen availability evaluations based on nitrogen mineralization potentials of soils and uptake of labeled and unlabeled nitrogen by plants. Int. J. on Plant-Soil Relationships 39 (1), 113-124.

Tremblay, N., Bouroubi, M.Y., Vigneault, P., Bélec, C., 2011. Guidelines for inseason nitrogen application for maize (Zea Mays I.) based on soil and terrain properties. Field Crops Res. 122, 157-182.

Van Ittersum, M.K., Leffelaar, P.A., Van Keulen, H., Kropff, M.J., Bastiaans, L., Goudriaan, J., 2002. Developments in modelling crop growth, cropping systems and production systems in the Wageningen school. NJAS-Wageningen J. Life Sci. 50 (2), 239-247.

Vanotti, M.B., Bundy, L.G., 1994a. An alternative rationale for corn nitrogen fertilizer recommendations. J. Prod. Agric. 7 (2), 243-249.

Vanotti, M.B., Bundy, L.G., 1994b. Corn nitrogen recommendations based on yield response data. J. Prod. Agric. 7 (2), 249.

Wang, D., Anderson, D.W., 1998. Direct measurement of organic carbon content in soils by the Leco CR-12 carbon analyzer. Commun. Soil Sci. Plant Anal. 29 (1-2), 15-21.

Wilson, J.P., Gallant, J.C., 2000. Digital terrain analysis. Terrain analysis: principles and applications 6 (12), 1-27.

Yang, J.M., Yang, J.Y., Liu, S., Hoogenboom, G., 2014. An evaluation of the statistical methods for testing the performance of crop models with observed data.

Agric. Syst. 127, 81-89. 


\section{Supplementary}
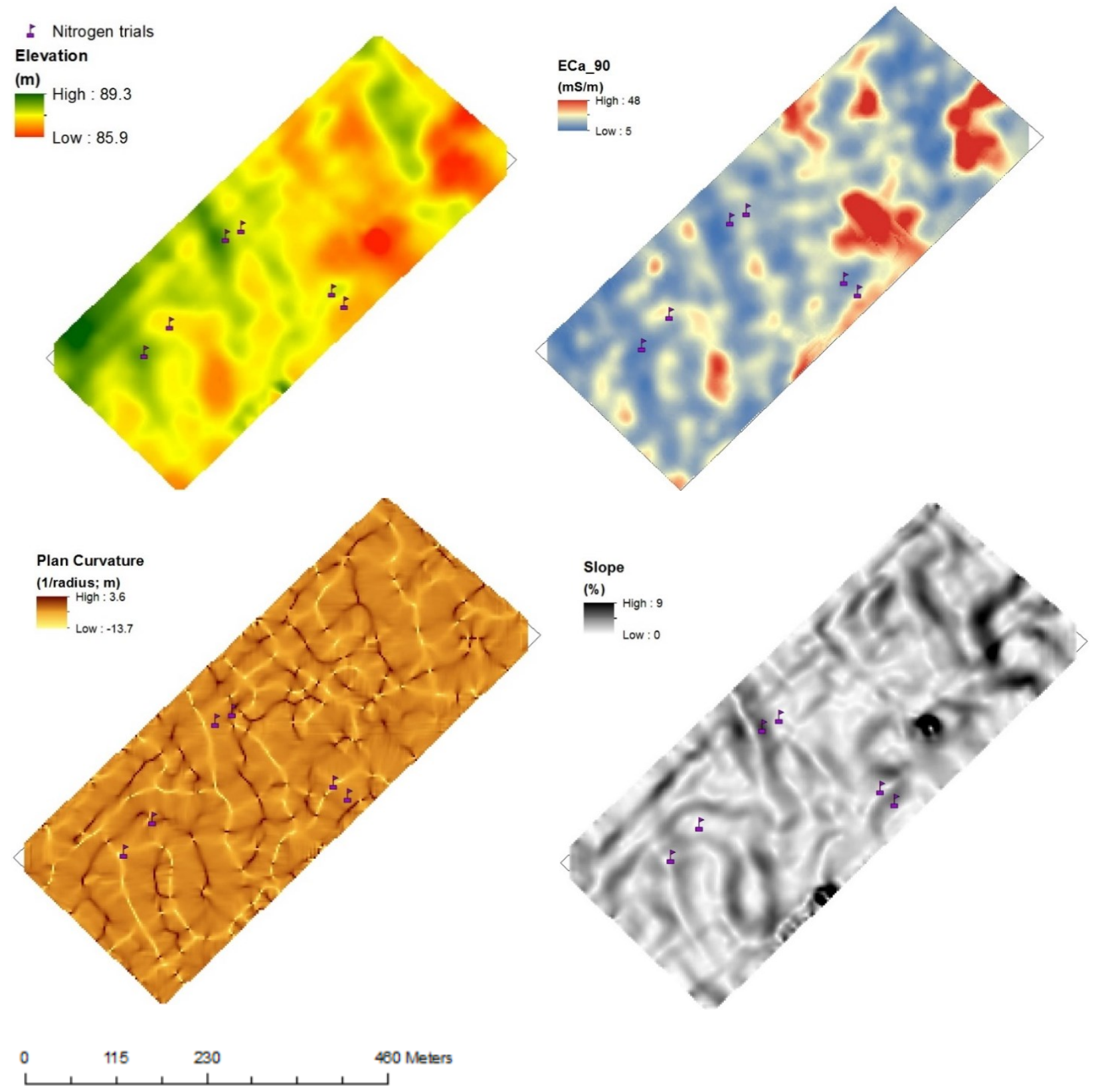

Figure S1. Elevation, apparent electrical conductivity at $90 \mathrm{~cm}$ depth (ECa), plan curvature, and slope maps. Purple flags show an example of the location of some trials. 


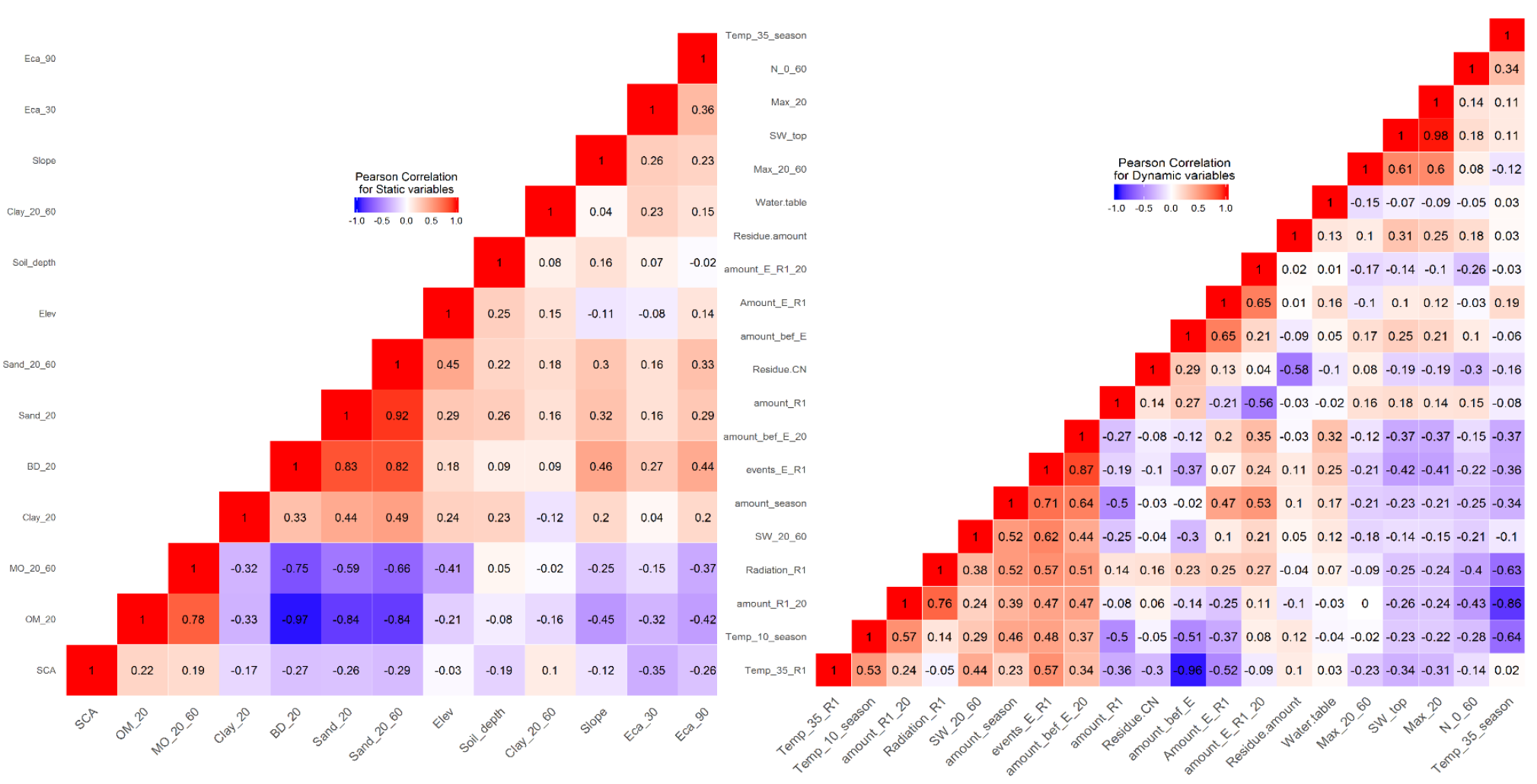

Cluster Dendrogram

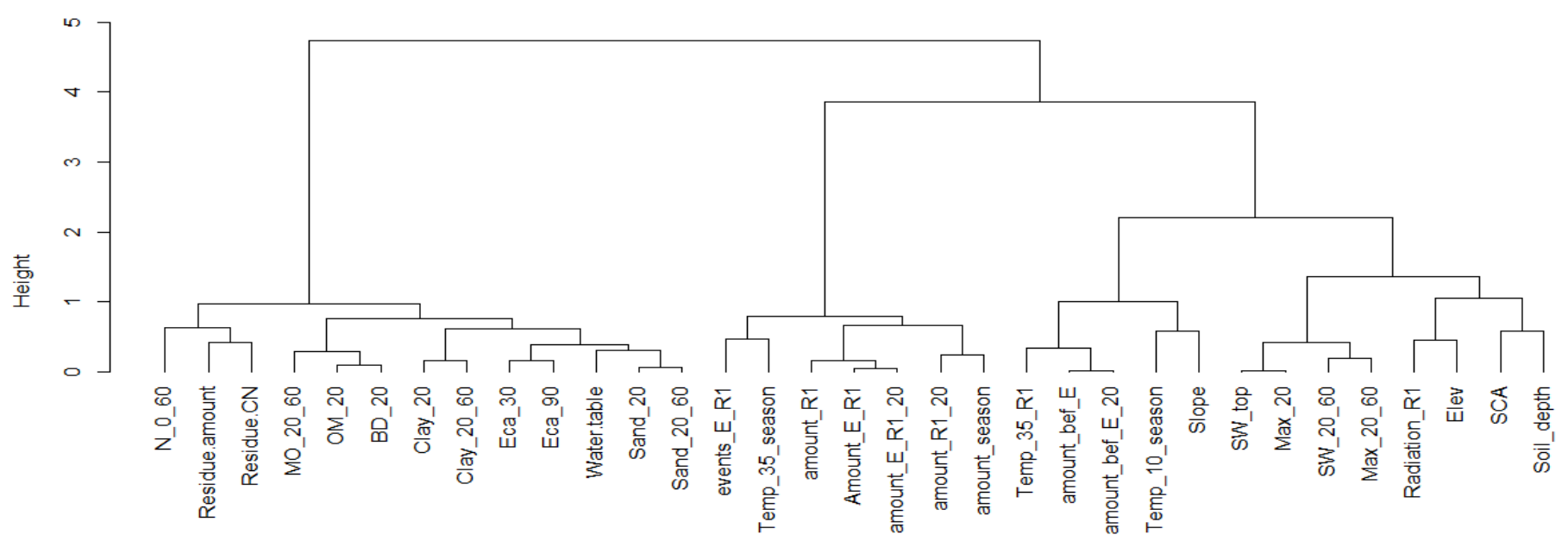

Figure S2. Pearson's correlation matrices for static and dynamic variables (top panel) and clustering analysis for the combination of static and dynamic variables. 

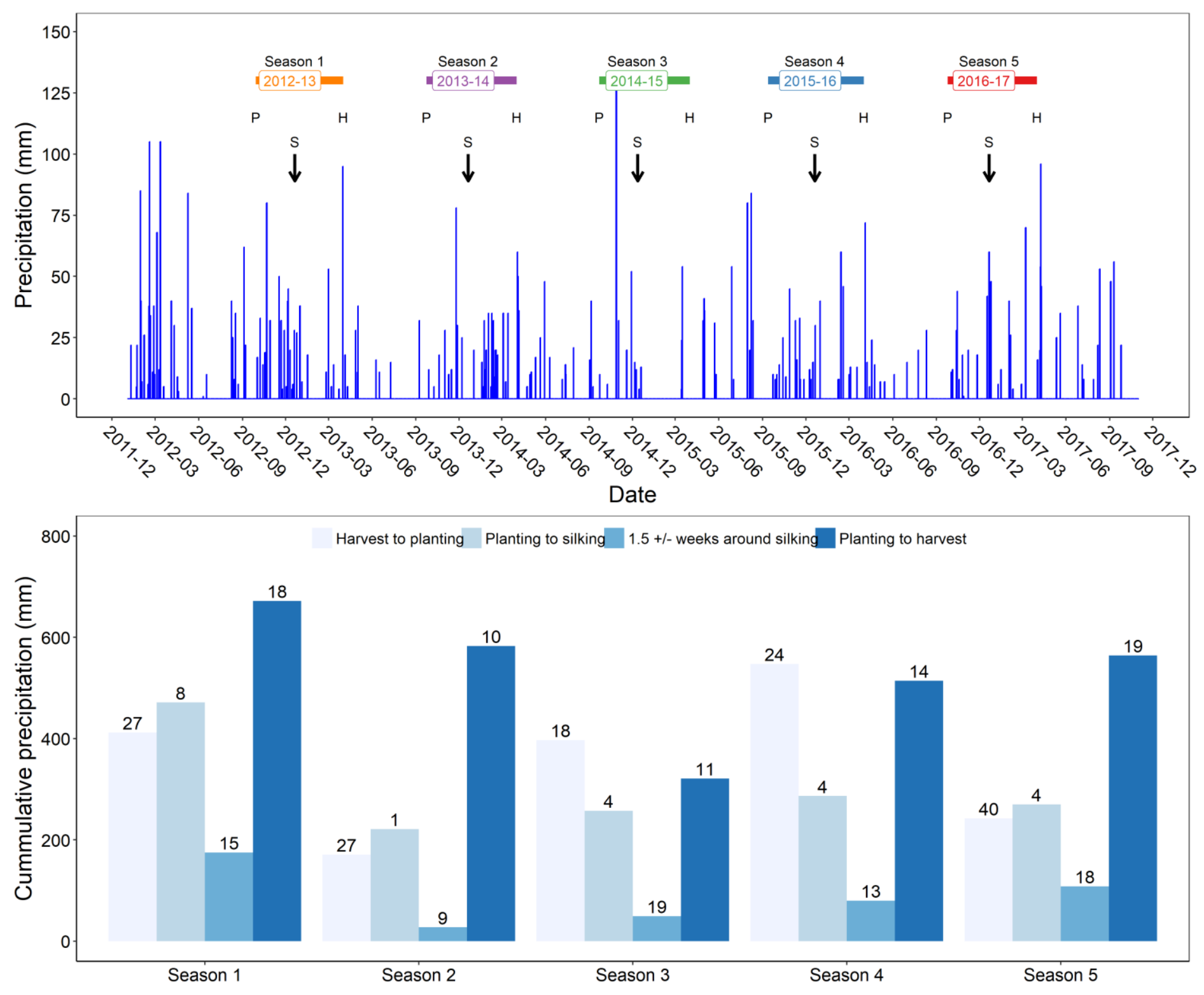

Figure S3. Daily precipitation in Central West Buenos Aires, Argentina (top panel) and cumulative precipitation for selected periods (bottom panel). Symbols used in the top panel, P, S, and H indicate planting, silking, and harvest time, respectively. In the bottom panel, numbers above the columns indicate number of precipitation events 


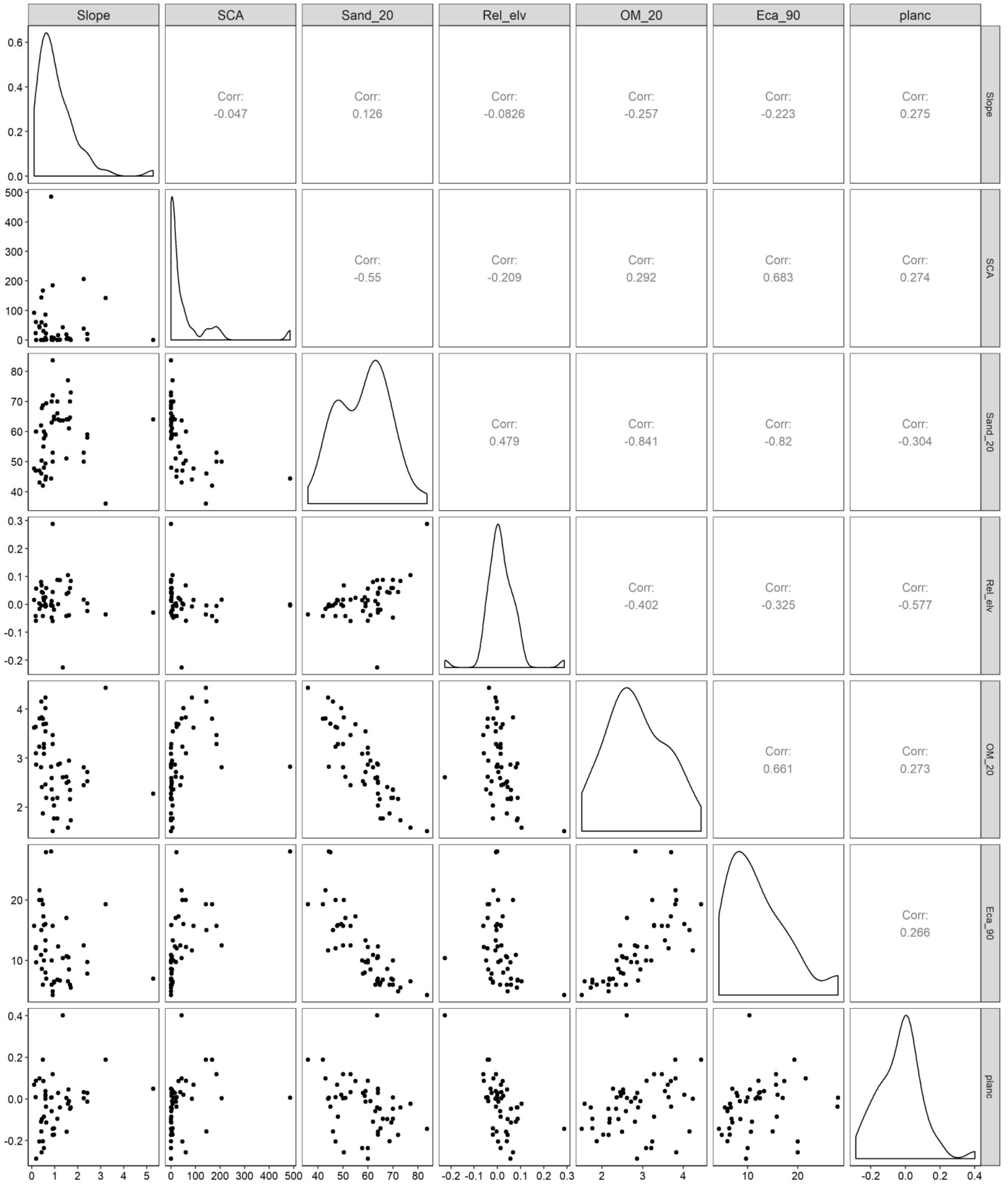

Figure S4. Correlation matrix between percent sand and soil organic matter at $20 \mathrm{~cm}$ (Sand_20 and OM_20), apparent electrical conductivity at $90 \mathrm{~cm}$ depth (ECa_90), and topographical derived parameters. Specific catchment area (SCA, pixel); percent of slope; relative elevation (Rel_elev, meters); plan curvature (degrees). Density plots of the variables are shown in the diagonal. 


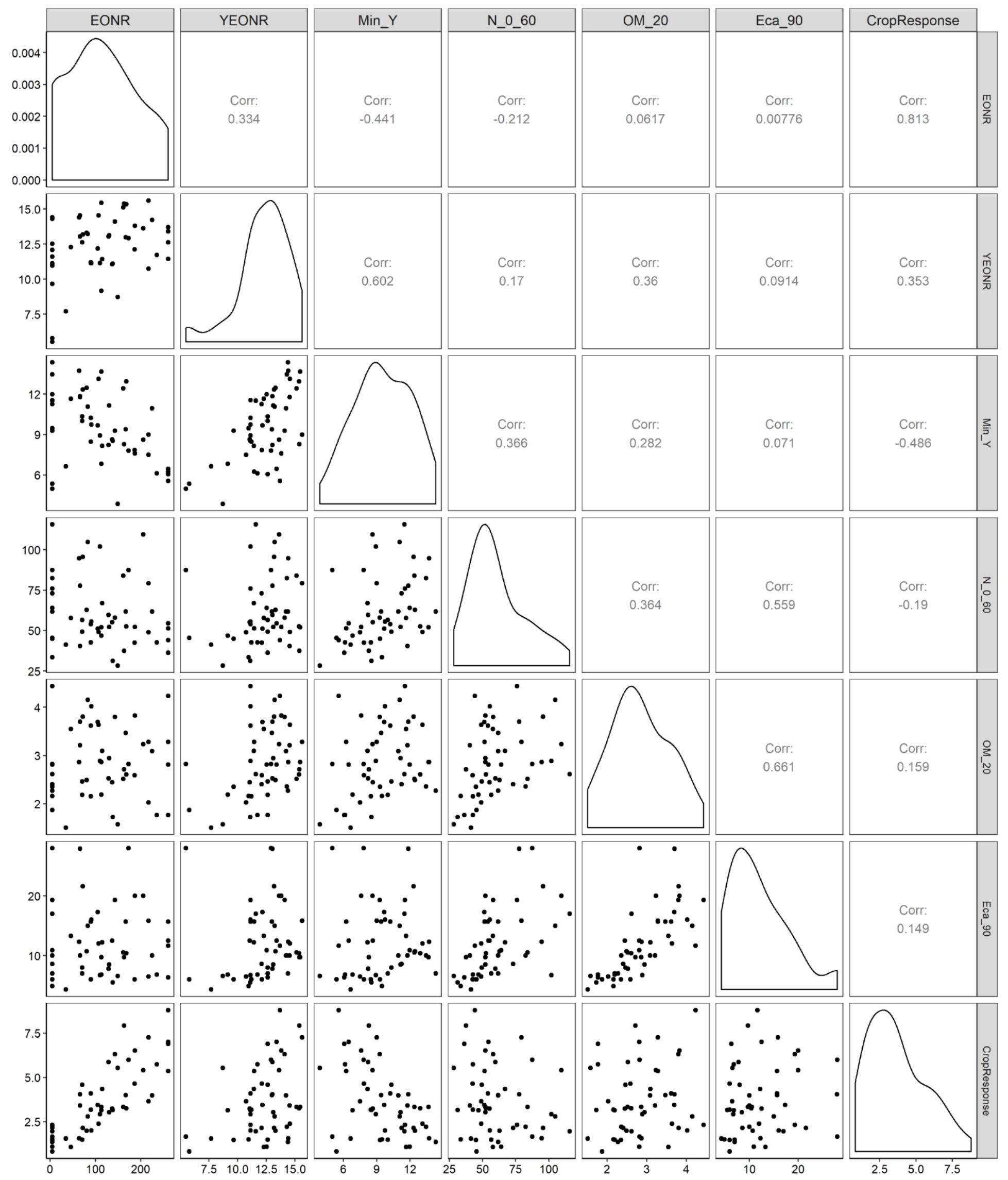

Figure S5. Correlation matrix between the economic optimum nitrogen rate (EONR), yield at EONR (YEONR), yiel at nitrogen zero (Yield_N0), difference between YEONR and Yield_N0 (CropResponse), percent sand and soil organic matter at $20 \mathrm{~cm}$ (Sand_20 and OM_20), soil nitrate (N_0_60, $\left.\mathrm{kg} \mathrm{N} \mathrm{ha}^{-1}\right)$, and apparent electrical conductivity at $90 \mathrm{~cm}$ depth (ECa_90). Density plots of the variables are shown in the diagonal. 


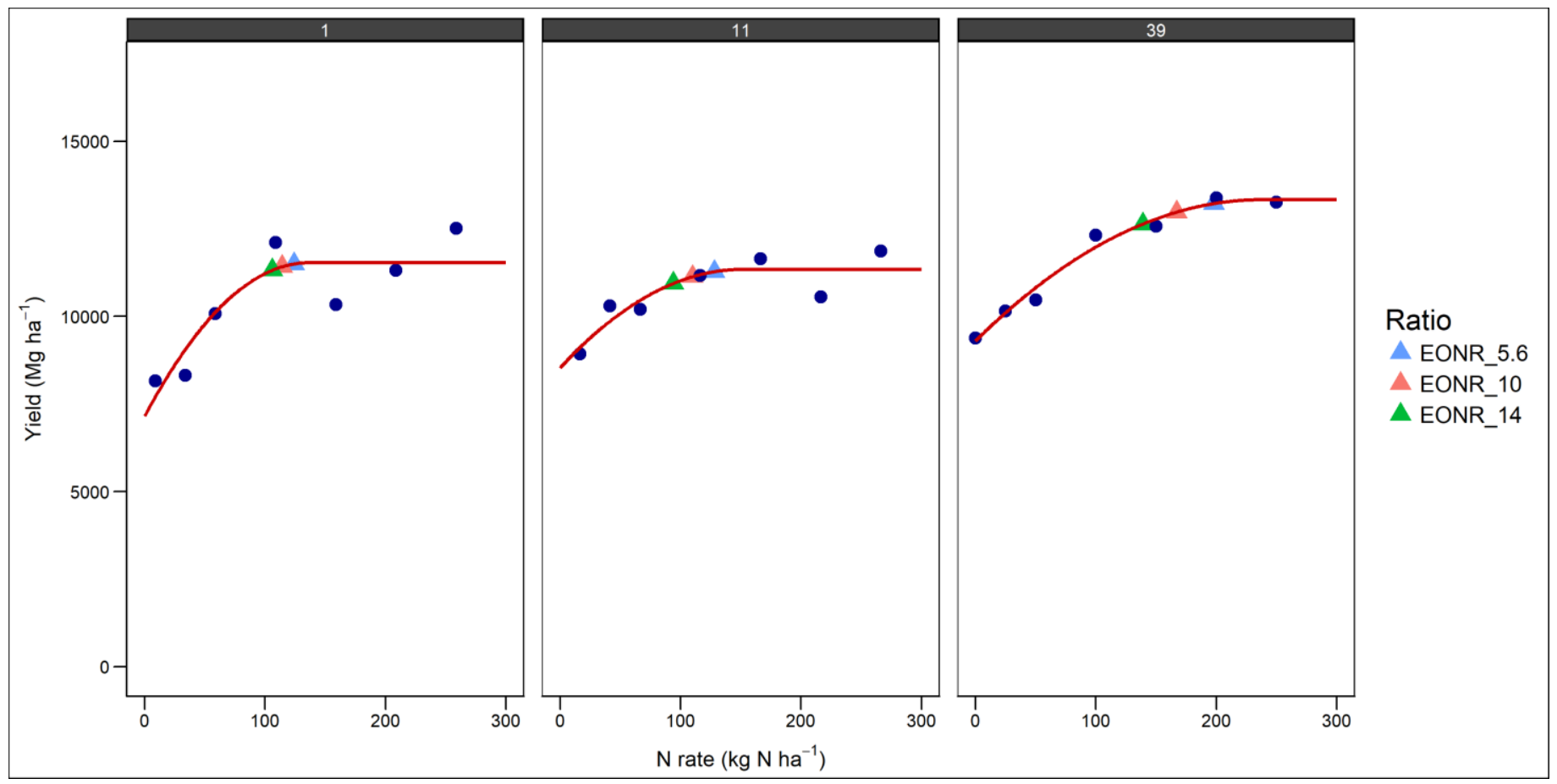

Figure S6. Sensitivity analysis of nitrogen price/grain price ratio on the economic optimum nitrogen rate (EONR). The value (ratio) of 10 was used in this study.
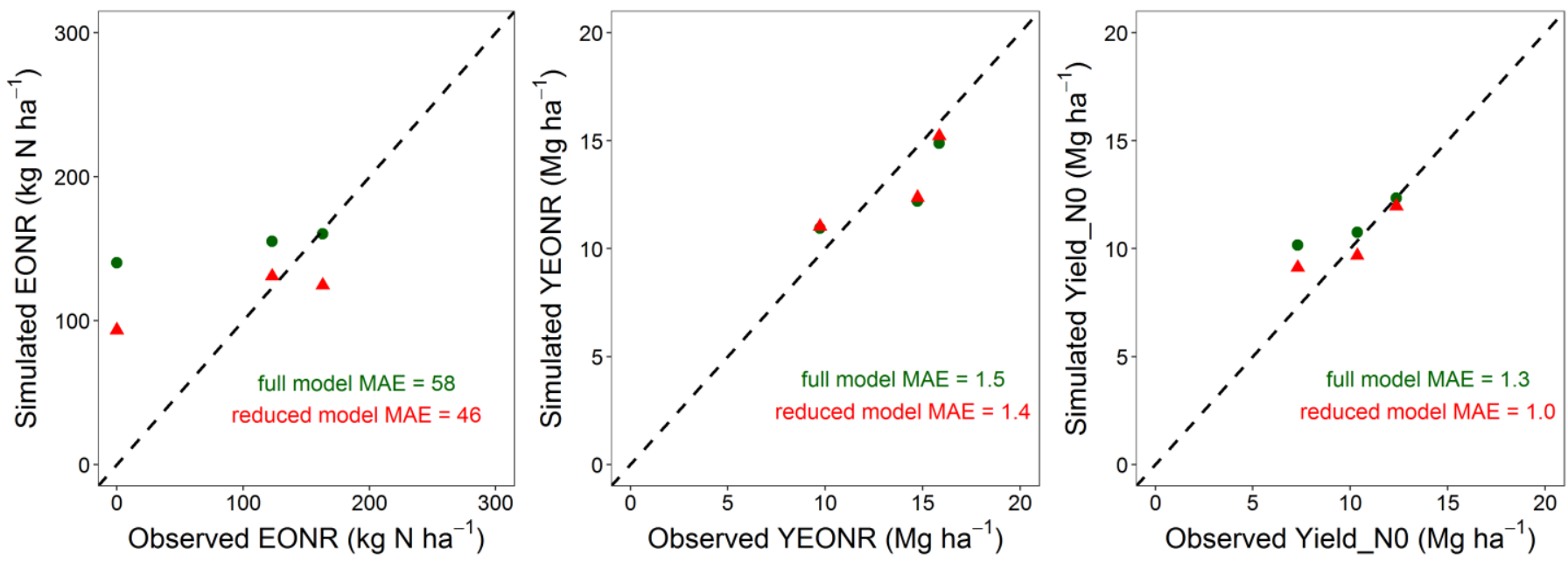

Figure S7. Predicted versus observed economic optimum N rate (EONR), yield at EONR (YEONR), and yield at non fertilizer (Yield_N0) for the validation data set using full model (circles) and reduced model (triangles). Diagonal dashed line shows 1:1 relationship. MAE is the mean absolute error. 
Table S1. Coefficient of determination (R2) for the fitting of 51 yield response to nitrogen trials.

\begin{tabular}{|c|c|c|}
\hline Trial ID & $\mathrm{R}^{2}$ & Model \\
\hline 1 & 0.61 & Quadratic-plateu \\
\hline 2 & 0.67 & Quadratic-plateu \\
\hline 3 & 0.87 & Quadratic-plateu \\
\hline 4 & 0.86 & Quadratic-plateu \\
\hline 5 & 0.91 & Quadratic-plateu \\
\hline 6 & 0.87 & Quadratic-plateu \\
\hline 7 & 0.90 & Quadratic-plateu \\
\hline 8 & 0.85 & Quadratic-plateu \\
\hline 9 & 0.91 & Quadratic-plateu \\
\hline 10 & 0.78 & Quadratic-plateu \\
\hline 11 & 0.60 & Quadratic-plateu \\
\hline 12 & 0.87 & Quadratic-plateu \\
\hline 13 & 0.61 & Quadratic-plateu \\
\hline 14 & NA & NA \\
\hline 15 & NA & NA \\
\hline 16 & 0.86 & Quadratic-plateu \\
\hline 17 & 0.55 & Quadratic-plateu \\
\hline 18 & 0.70 & Quadratic-plateu \\
\hline 19 & NA & NA \\
\hline 20 & 0.78 & Quadratic-plateu \\
\hline 21 & NA & NA \\
\hline 22 & 0.61 & Quadratic-plateu \\
\hline 23 & 0.44 & Quadratic-plateu \\
\hline 24 & 0.50 & Quadratic-plateu \\
\hline 25 & 0.69 & Quadratic \\
\hline 26 & 0.76 & Quadratic-plateu \\
\hline 27 & 0.83 & Quadratic-plateu \\
\hline 28 & 0.73 & Quadratic-plateu \\
\hline 29 & NA & NA \\
\hline 30 & NA & NA \\
\hline 31 & 0.48 & Quadratic-plateu \\
\hline 32 & 0.50 & Quadratic-plateu \\
\hline 33 & 0.94 & Quadratic-plateu \\
\hline 34 & 0.52 & Quadratic-plateu \\
\hline 35 & 0.83 & Quadratic-plateu \\
\hline 36 & 0.65 & Quadratic \\
\hline 37 & NA & NA \\
\hline 38 & 0.85 & Quadratic-plateu \\
\hline 39 & 0.75 & Quadratic-plateu \\
\hline 40 & 0.69 & Quadratic-plateu \\
\hline 41 & 0.55 & Quadratic-plateu \\
\hline 42 & 0.85 & Quadratic-plateu \\
\hline 43 & 0.89 & Quadratic-plateu \\
\hline 44 & 0.65 & Quadratic-plateu \\
\hline
\end{tabular}




\begin{tabular}{ccc}
45 & 0.69 & Quadratic-plateu \\
46 & 0.93 & Quadratic-plateu \\
47 & NA & NA \\
48 & NA & NA \\
49 & 0.87 & Quadratic-plateu \\
50 & 0.78 & Quadratic-plateu \\
51 & NA & NA \\
\hline
\end{tabular}

* In case of non-responsive trials $\mathrm{R}^{2}$ is N/A. 